\title{
Influence of Increasing Concentrations of Organic Pollutants on Biofilm Formation and Flow Parameters in a Sand-aquifer and Its Capillary Fringe.
}

\author{
Daniel Jost ${ }^{*}{ }^{1}$, Josef Winter ${ }^{2}$, Claudia Gallert ${ }^{3}$ \\ ${ }^{1}$ Project Management Agency Karlsruhe, Department Water Technology, Karlsruhe Institute of Technology, \\ Eggenstein-Leopoldshafen, Germany \\ ${ }^{2}$ Institut für Ingenieurbiologie, Karlsruhe Institute of Technology, Karlsruhe, Germany \\ ${ }^{3}$ University of Applied Science Emden/Leer, Department for Microbiology \& Biotechnology, Emden, Germany \\ Email: daniel.jost@kit.edu
}

\begin{abstract}
We followed the development of a Pseudomonas fluorescens biofilm on quartz sand in an instrumented horizontal flow-through stainless steel container (SSC) in lysimeter-scale, to investigate its impact on physical soil parameters within the aquifer and the capillary fringe $(\mathrm{CF})$. Increasingly concentrated biodegradable substances in a liquid medium were pumped through the sand in the SSC creating an artificial aquifer. Biofilm development and its influence on flow parameters and oxygen concentration profiles, as well as temperature or water suction changes with time were determined. After more than 19 weeks of medium flow, at DOC concentrations of finally about $300 \mathrm{mg} / \mathrm{L}, P$. fluorescens formed a strong biofilm and the highest biomass concentrations with up to $2.8 \mathrm{mg}$ volatile solids per $g$ dry sand were found in the transition zone of the CF. The soil temperature, which was slightly increased, or the water suction was significantly influenced during the experiment. The effects were strongest within the first $0.3 \mathrm{~m}$ of flow stretch, where the highest biomass values were detected. During the total experimental duration of 54 weeks the average flow velocity was reduced by up to $15 \%$ due to clogging effects and the oxygen profiles were changed drastically. Results may be representative for real polluted aquifers.
\end{abstract}

Keywords: Pseudomonas fluorescens, sand aquifer, capillary fringe, soil contamination, biofilm formation, biological clogging.

\section{Introduction}

Soil and groundwater are naturally inhabited by a vast variety of prokaryotes. It was estimated that 2.5 $\mathrm{x} 10^{29}$ microorganisms live in the top $8 \mathrm{~m}$ of the terrestrial subsurface and at least $2.5 \times 10^{30}$ microorganisms below $8 \mathrm{~m}$ depth, either suspended in the water phase or attached onto organic and mineral compounds of top soil and the underground [53]. Anaerobic bacteria in deep soil layers may ferment organic pollutants to mainly fatty acids whereas aerobic bacteria in upper soil layers may respire organic pollutants in the presence of oxygen to carbon dioxide and thus contribute to "clean-up". There seems to be a spatial heterogeneity of microorganisms. Whereas mainly aerobic bacteria, fungi and protozoa colonize soil surface layers, the proportion of mainly anaerobic bacteria (most of them are "fermenters") and of Actinomycetes increases with depth in the underground in the vicinity and below the groundwater table. These population changes are accompanied by a significantly decreasing diversity of microorganisms [17] and by a decrease of physiological functions [45]. Groundwater bacteria tend to form a biofilm on mineral surfaces of soil particles and may cause preferential flow paths or clogging in heterogeneous soil compartments [45]. In contrast aerobic motile bacteria can even move into the top zone of the capillary fringe $(\mathrm{CF}$, spanning from the groundwater table to still visible moisture above it in a quartz sand aquifer) above the water-saturated zone of quartz sand and form a dense biofilm in the still highly saturated interface region of the $\mathrm{CF}$ [31]. Biofilm formation in a substrate-limited, watersaturated underground and in the $\mathrm{CF}$ is however a very slow process due to severe nutrient limitation in this often still pristine oligotrophic environment [18], [19], [20] and [25]. Single aspects of biofilm formation have been reviewed previously by [43], covering among others the changes of the 
"morphological structure of the extracellular polymeric substances (EPS) matrix under varying hydration states, its role in maintenance of aquatic microhabitats and facilitating nutrient diffusion under desiccated conditions, and potential modification of macroscopic hydrologic properties of host porous media". Biofilm formation by a mixed population of soil bacteria and flow characteristics during vertical infiltration of slightly polluted water in the low $\mathrm{mg} / \mathrm{L}$-range, into a water-saturated soil of $1.2 \mathrm{~m}$ depth in a lysimeter was investigated by [45]. Microbial processes in the heterogeneous soil of the lysimeter apparently reduced the infiltration rate. A depth zonation of the microorganisms in the biofilm on soil grains was found after 84 days and EPS at all depths of the lysimeter seemed to be responsible for the changes of flow characteristics. Drying cycles allowed re-saturation of the soil with oxygen even in the depth, and after re-wetting the growth of microorganism in the biofilm on soil particles was continuing, indicating survival of the bacteria in the biofilm. This led to further decreasing infiltration rates [16] and may finally cause biological clogging.

First attention of bacterial biofilm formation came from medicine, when microorganisms growing in or forming mucous surfaces were recognized as a common cause of persistent infections [13]. Biofilm formation however is also a common feature of soil bacteria [20]. It requires adaption of the bacteria to the environmental conditions in soil, such as maintaining hydration to overcome dryness, metabolic variability at different nutrition states and genetic mutations, e.g. to express genes for EPS and biofilm formation [43]. For studies of biofilm formation in soil often Pseudomonas strains, common inhabitants of soil, and structurally defined "soil conditions", as for instance in glass pebble beds, were used [12], [24], [43], [54] or [50]. Stress conditions such as dryness apparently promoted EPS production by Pseudomonas putida most and consequently led to biofilm formation [46]. Theoretically the thickness of a biofilm depends on the continuity of nutrient supply, the strength of attachment e.g. by electrostatic forces or formation of EPS [43], the nutrient concentration and the electron acceptor availability for aerobic respiration [16]. The highest cell masses are obtained if sufficient oxygen is available for respiration of carbon sources, since the energy gain of maximally 38 mol ATP per mol glucose is much higher than that for other respiration or fermentation pathways [21].

In-situ growth of microorganism as a biofilm at the expense of a spatially separated supply of glucose and nitrate in a "small stripe" between electron donor and electron acceptor was investigated in twodimensional experiments under water-saturated up-flow conditions by visible light transmission [50]. The observed dispersion of bacterial growth with time may have been caused by nitrogen gas bubble formation during denitrification in the growing biofilm.

The development of a bacterial biofilm by excretion of an EPS hydrogel on the surface of solid minerals in the underground apparently depends on favorable growth-supporting conditions and may increasingly reduce water permeability, nutrient and oxygen fluxes by narrowing pore diameters or may change surface roughness and positive or negative electrical charges of the overgrown soil minerals [43], [50]. Due to very low flow rates of groundwater without turbulence, non-motile and motile bacteria as well may at first passively and later on actively attach to mineral surfaces at places or in the vicinity of a growth-supporting environment to start formation of a finally tightly attached, permanent biofilm [24].

Whereas investigations on pollution of the aquifer in up-flow direction in water-saturated soil in the meter-scale in a lysimeter have been reported over a period of 84 days [45], [16] to our knowledge no long-term horizontal flow experiments of groundwater in this scale under defined conditions are available. Thus we performed three-dimensional long-term horizontal flow-through experiments in an instrumented stainless steel container (SSC) of lysimeter size through well-defined quartz sand and its CF. Biofilm formation by Pseudomonas fluorescens, a typical soil bacterium, on the surface of the sand and its influence on flow characteristics during horizontal flow of a medium with subsequently increasing and decreasing concentrations of organic substances and at changing flow velocities was investigated. Suspended bacteria in the pore water of the SSC experiment were quantified microscopically throughout the experiment. This approach allowed non-invasive investigations of the changes of flow characteristics or other physical soil parameters during biofilm development in a defined sand aquifer.

\section{Materials and Methods}

A long-term experiment was performed in the laboratory to determine growth and biofilm formation of $P$. fluorescens and the influence of a biofilm on the flow-through behavior of a liquid, only soluble 
organic substances containing medium through a quartz sand aquifer. A three-dimensional quartz sand aquifer in a $0.375 \mathrm{~m}^{3}$ stainless steel container (SSC) was used to investigate biofilm formation by $P$. fluorescens and the effect of a growing biofilm on hydrologic parameters and oxygen concentrations in the water-saturated zone and the capillary fringe $(\mathrm{CF})$.

\subsection{Stainless Steel Container (SSC)}

The SSC (Figure 1) for long-term experiments had a dimension of $1.0 \times 0.75 \times 0.5 \mathrm{~m}$ (length, $\mathrm{L} \times$ height, $\mathrm{H} \times$ width, $\mathrm{W}$ ) and was filled with quartz sand to a height of $0.47 \mathrm{~m}$. At both container ends, respectively, inflow and outflow chambers $(0.05 \mathrm{~m}$ width) were separated from the sand volume by perforated steel sheets (Figure 1). The sand bulk volume of the SSC was $0.212 \mathrm{~m}^{3}$. At a water table height of $0.1 \mathrm{~m}$, inflow and outflow chambers contained $2.5 \mathrm{~L}$ of the medium that slowly flew through the sand. The inflow chamber guaranteed an equal infiltration and the outflow chamber an even drainage of the medium out of the sand. A hydraulic gradient of approx. 0.006 (0.005 m water level difference after $0.9 \mathrm{~m}$ flow distance) could thus be maintained from the inflow of the medium into the sand body to the outflow chamber of the SSC. Several probes were installed during the sand filling procedure (see below). Probe distances to the inflow chamber were 0.32-0.35 m (position $\mathrm{X}_{\mathrm{P} 1}$ ) and 0.70$0.73 \mathrm{~m}$ (position $\mathrm{X}_{\mathrm{P} 2}$ ) (Figure 1). Thus, soil moisture tensions, temperature values or oxygen concentrations at different heights of the sand at $\mathrm{X}_{\mathrm{P} 1}$ and $\mathrm{X}_{\mathrm{P} 2}$ could be monitored continuously during the experiment. The probes were either mounted tightly into the side walls of the SSC or vertically fixed with thin acrylic-glass columns. The dimensions of the SSC allowed taking sand samples for analysis of attached biomass close to the inlet and the outlet as well as in between. After careful refilling of the holes with fresh sand no drastic disturbance of the flow behavior was expected.

Quartz sand and filling procedure. A customized Rhine sand fraction with a grain size diameter of $2 \times 10^{-4}-6 \times 10^{-4} \mathrm{~m}$ (Weisenburger GmbH, Karlsruhe, Germany) was used for the experiments. The sieved fraction had a porosity of $\mathrm{n}=0.38$, as determined from the bulk volume of a known amount of dried sand minus the volume of the sand that was calculated from its specific density $\left(2.65 \mathrm{~kg} / \mathrm{m}^{3}\right)$. It was heat-sterilized for $12 \mathrm{~h}$ at $200{ }^{\circ} \mathrm{C}$ in a muffle furnace. The hydraulic conductivity was $\mathrm{K} \approx 1.4 \times 10^{-4}$ $\mathrm{m} \mathrm{s}^{-1}$, as determined by application of a constant hydraulic gradient in the sand in a Plexiglas® cylinder according to DIN 18130-1 [15]. K was calculated using the Darcy equation (1),

$$
K=Q \cdot f / A \cdot h
$$

where $\mathrm{Q}=$ flow through $\left[\mathrm{m}^{3} / \mathrm{s}\right], \mathrm{l}=$ length of flow $[\mathrm{m}], \mathrm{A}=$ cross section area $\left[\mathrm{m}^{2}\right], \mathrm{h}=$ hydraulic difference $[\mathrm{m}]$. To obtain homogeneous sand packing the quartz sand was evenly scattered into the SSC in small portions with a sieve or a cone, respectively. De-ionized sterile water was successively filled into the inflow chamber of the SSC to maintain a water level of approx. $0.05 \mathrm{~m}$ above the sand during the filling procedure. After reaching a filling height of $0.47 \mathrm{~m}$ in the SSC the quartz sand was drained through an outflow port in $0.05 \mathrm{~m}$ height above the bottom of the SSC.

The top of the CF at a water table height of $0.1 \mathrm{~m}$ was assumed at $0.32 \mathrm{~m}$ height above the bottom (Fig. 1). The height of the CF $(0.32-0.1=0.22 \mathrm{~m})$ was determined in a parallel experiment in a HeleShaw cell that was filled with the same sand. After formation of the $\mathrm{CF}$ small sand layers were successively removed from top to bottom and their water content was calculated after drying at $105^{\circ} \mathrm{C}$. According to the water content (Fig. S1) the transition zone of the CF was defined to be approx. between 5 and $12 \mathrm{~cm}$ above the water table.

Inoculation of the SSC. For inoculation of the SSC after "wet" filling with sand and drainage of the de-ionized pore water a freshly grown $P$. fluorescens suspension in 10-fold diluted M535 medium $\left(0.98 \mathrm{~g} / \mathrm{L}\right.$ DOC, composition see below), containing $2 \times 10^{10}$ cells/L was filled into the inflow chamber. The inoculation procedure was continued by "flushing" the suspension into the sand for $2 \mathrm{~h}$ with a high pumping rate $\mathrm{Q}$ of $10 \mathrm{~L} / \mathrm{h}$ to avoid immediate adsorption of cells to the sand grains and to guarantee an almost even distribution of $P$. fluorescens cells in the void volume of the sand in the SSC as controlled by microscopic counting. After inoculation $0.12 \mathrm{~L} / \mathrm{h}$ of sterile 200 -fold diluted M535-medium was pumped through the SSC for 2 weeks. Even after 2 weeks a relatively high number of $5 \times 10^{7}-1 \times 10^{8} P$. fluorescens cells/L was determined in the outflow chamber, indicating that $P$. fluorescens grew in the sand aquifer. Then experimental phases I - VI (medium and flow-through conditions, see Table 1) were started. All experiments in the SSC were performed in a temperature-controlled room at minimally 
$19.4{ }^{\circ} \mathrm{C}$ during the night and maximally $20.6{ }^{\circ} \mathrm{C}$ during day time, when persons entered the room frequently.

Table 1. Media concentrations, inflow rates and duration of experimental phases in the SSC-experiment, after initiation of biofilm formation with P. fluorescens for two weeks. * Plus additional point source contamination at $\mathrm{x}$ $=0.5 \mathrm{~m}$

\begin{tabular}{l|c|c|c|c|c|c}
\hline Phase & I & II & III & IV & V & VI* \\
\hline Dilution of M535 & 100 -fold & 50 -fold & 25 -fold & 50 -fold & 50 -fold & 50 -fold \\
\hline DOC of medium $[\mathrm{mg} / \mathrm{L}]$ & 98 & 196 & 395 & 196 & 196 & 196 \\
\hline DOC load $\left[\mathrm{mg} / \mathrm{L}^{*} \mathrm{~h}\right]$ & 11.8 & 23.5 & 47.4 & 47.0 & 23.5 & 23.5 \\
\hline Flow rate Q [mL/h] & 120 & 120 & 120 & 240 & 120 & 120 \\
\hline Operation time $[\mathrm{d}]$ & 60 & 60 & 60 & 100 & 100 & 60 \\
\hline
\end{tabular}

\subsection{Cultivation of P. Fluorescens}

For the experiments P. fluorescens DSM 4358 (DSMZ, Braunschweig, Germany), a typical heterotrophic soil bacterium was used, which can grow aerobically by oxygen respiration or anoxically by nitrate respiration [36]. P. fluorescens was grown in medium M535 (Merck, Darmstadt, Germany), containing $17 \mathrm{~g}$ peptone from casein, $3 \mathrm{~g}$ peptone from tryptically digested soy meal, $2.5 \mathrm{~g} \mathrm{D}(+)$-glucose monohydrate, $5 \mathrm{~g} \mathrm{NaCl}$ and $2.5 \mathrm{~g}$ di-potassium hydrogen phosphate per $\mathrm{L}$ at a $\mathrm{pH}$ of $7.3+/-0.2$. The dissolved organic carbon (DOC) concentration of M535 was $9.8 \mathrm{~g} / \mathrm{L}$. Only amino-N was present in the M535 medium. P. fluorescens was grown freshly each week in $40 \mathrm{ml}$ portions of M535 medium in cotton plugged $0.1 \mathrm{~L}$ shake flasks at $20^{\circ} \mathrm{C}+/-1^{\circ} \mathrm{C}$ and $200 \mathrm{rpm}$ on a rotary shaker. The optical density of cell cultures was determined at a wavelength of $578 \mathrm{~nm}$ with a photometer and life-dead staining was performed with a test kit of Thermo Fisher Scientific (Waltham, Mass, USA). After about 8 h of aerobic growth a blue-fluorescing luminophore was expressed by $P$. fluorescens cells, which could be quantified under UV-light (excitation wavelength: $365 \mathrm{~nm}$ ). Fluorescence intensities of P. fluorescens cell suspensions in quartz sand were related to cell densities according to [33].

No EPS was excreted in shake cultures within $24 \mathrm{~h}$ as determined by microscopy after ink-staining of EPS. Furthermore it was assumed that in a biofilm on sand grains shadowing of the fluorescence by EPS did not significantly influence its intensity since the biofilm was only a few cell layers thick as determined by reflected-light microscopy.

The maximal growth rates of $P$. fluorescens at $20{ }^{\circ} \mathrm{C}$ were $\mu=0.571 / \mathrm{h}\left(\right.$ doubling time $\mathrm{t}_{\mathrm{d}}=\ln 2 / \mu=$ $1.22 \mathrm{~h})$ for aerobic growth and $\mu=0.131 / \mathrm{h}\left(\mathrm{t}_{\mathrm{d}}=5.33 \mathrm{~h}\right)$ for anaerobic growth. The growth rates were calculated from growth curves, measuring the optical density $\left(\mathrm{OD}_{578 \mathrm{~nm}}\right)$ and DOC utilization using the Monod equation (2)

$$
\mu=\mu \max \cdot S /(K S+S)
$$

A KS value (concentration of DOC at which half-maximal growth occurs) of $0.18 \mathrm{~g} / \mathrm{L}$ DOC was derived from growth parameters in 5-, 10-, 20- and 50-fold diluted M535-medium. P. fluorescens was an ideal microorganism for long-term aseptic, but non-sterile lab experiments, since it had a higher affinity for nitrate and easily degradable carbon sources than other soil bacteria that might compete in an anoxic environment. It could grow under aerobic, anoxic and anaerobic conditions as well [36], [42] and thus was used as a versatile microorganism to test the microbial growth behavior in/on soil and groundwater.

During aerobic incubation with non-restricted oxygen supply approximately $34 \%$ of the DOC of the M535 medium was consumed in $24 \mathrm{~h}$. The dry weight of aerobically grown cells in a shake culture was $3.1 \mathrm{~g} / \mathrm{L}$, resulting in a yield of $0.93+/-0.02 \mathrm{~g}$ dry biomass per $\mathrm{g}$ DOC $(\mathrm{g}$ DOC is represented by approximately $2.5 \mathrm{~g}$ organic substances in M535) consumed at surplus substrate supply. Hence for growth within the CF in quartz sand, where the oxygen supply is restricted, a much lower yield can be assumed. 


\subsection{General Experimental Procedure}

For all experimental phases in the SSC initially diluted autoclaved M535-medium with successively increasing concentration of nutrients, as stated in Table 1, was pumped from a $10 \mathrm{~L}$ carboy at a flow rate of $0.12 \mathrm{~L} / \mathrm{h}$ into the inflow chamber of the SSC with a peristaltic pump (Gilson, Limburg, Germany). The carboy was replaced when the $10 \mathrm{~L}$ medium was used up. The concentration of organic substances in the SSC was stepwise increased from initially 200-fold diluted M535 medium by pumping in 100-, 50 and 25-fold diluted M535 medium at the same flow rate (phases I - III, Table 1) and thus increasing the DOC load in the sand aquifer. The DOC load of about $0.047 \mathrm{~g} /(\mathrm{Lh})$ in phase III was maintained in phase IV by doubling of the flow rate of 50-fold instead of 25-fold diluted M535 medium and was reduced by $50 \%$ in phase $\mathrm{V}$ by respectively reducing the medium flow rate (Table 1). After phase $\mathrm{V}$ a continuous flow of 50-fold diluted M535 medium was further maintained in the SSC for another 60 days as a basic flow.

To simulate a highly concentrated point source contamination from top of the sand in the SSC that percolates towards the groundwater undiluted M535 medium was infiltrated underneath the sand surface (approx. $0.05 \mathrm{~m}$ above the $\mathrm{CF}$ ) during the first 6 weeks in phase VI at a distance of $50 \mathrm{~cm}$ from the inflow chamber. Phase VI was performed to simulate possible groundwater pollution for instance by leaking sewers under field conditions, where contaminants also trickle through a $\mathrm{CF}$ in the respective soil.

The outflow port of the outflow chamber was mounted at $0.095 \mathrm{~m}$ height. At the beginning of the experiment an average flow velocity of $\mathrm{v}_{\mathrm{a}}=0.336 \mathrm{~cm} / \mathrm{h}$ (hydraulic gradient of 0.006 ) was calculated from the medium flow rate and the pore water content of the sand. The pore water volume of the sand in the SSC (excluding inflow and outflow chambers) was approx. $24 \mathrm{~L}$. The hydraulic retention time (HRT) of the water in the aquifer was approx. 6.5 days at the beginning of the experiment.

Temperature and water suction. To investigate the influence of bacterial growth on physical parameters in the SSC respective sensors were installed at $0.32 \mathrm{~m}\left(\mathrm{X}_{\mathrm{P} 1}\right)$ and at $0.7 \mathrm{~m}\left(\mathrm{X}_{\mathrm{P} 2}\right)$ distance from the inflow chamber (Figure 1). The probes were vertically fixed beginning at the water table and further in different heights above the water table (Figure 1). Tensiometers were constructed with pressure sensors (Conrad, Germany) that were mounted on slightly angled acrylic glass tubes (length: $0.15 \mathrm{~m}$, inner diameter: $0.005 \mathrm{~m}$ ) and a $0.02 \mathrm{~m}$ long, round bottom ceramic ending (UMS, Munich, Germany). The pressure sensors were initially calibrated with a water reservoir, which was connected to a silicon-tube, for different water level heights ( $\mathrm{cm}$ water column) to simulate positive and negative water pressure respectively. At each probe position $\mathrm{X}_{\mathrm{P} 1}$ and $\mathrm{X}_{\mathrm{P} 2}$ six tensiometers were inserted from the side wall of the SSC, using stainless steel gaskets (Sautter, Germany), into the sand of the container, beginning $0.1 \mathrm{~m}$ above the bottom up to $0.3 \mathrm{~m}$, in $0.04 \mathrm{~m}$ distance from each other to measure the soil moisture tension or the matrix potential $\psi_{\mathrm{m}}$ (in mbar or $\mathrm{cm}$ water column) in the water-saturated sand and in the CF. The pressure sensors were connected to an AM16/32 channel relay multiplexer C/W SP and their signals were fed into a "Loggernet Datalogger CR1000 measurement and control module" (Campbell Scientific, Bremen, Germany). For temperature measurements PT100 probes were installed in the SSC at $\mathrm{X}_{\mathrm{P} 1}$ and $\mathrm{X}_{\mathrm{P} 2}$ and also connected to the relay multiplexer. The support software allowed reading of raw resistance data $\mathrm{R}[\Omega, \mathrm{Ohm}]$ of the PT100 divided by a standard control resistance of 1000 Ohm. A one point calibration in water + crushed ice (providing $0{ }^{\circ} \mathrm{C}$ ) was done based with these Ohm/Ohm-values by multiplication with a specific material constant for each temperature sensor. Respective room temperatures were measured and were subtracted from the temperatures measured in the SSC respectively, for a better and day time independent comparison of the values.

Oxygen measurements. Oxygen concentrations were measured by applying a non-invasive optode technique, based on luminescence quenching of a 'luminophore' by oxygen (e.g. [35], [39] or [51]). Twenty oxygen-sensitive luminophore foil spots (SF-PSt3-NAU-D3-YOP, PreSens, Precision Sensing GmbH, Regensburg, Germany) were glued onto the endings of polymer optical fibers (Presens, Germany) and inserted into the sand in the neighborhood of tensiometers and temperature probes at $\mathrm{X}_{\mathrm{P} 1}$ und $\mathrm{X}_{\mathrm{P} 2}$ in the SSC (Figure 1). The optical fibers (length: $2.5 \mathrm{~m}$ ) were connected to a multiplexer. From there the optode sensor signals were sent to a light signal transducer (Fibox 3, Presens, Regensburg, Germany) by using a "PANDRIVE 42MM" step motor (Conrad, Germany), and converted to the oxygen concentration $\mathrm{cO}_{2}[\%]$. Applying this method, oxygen concentrations between 0 and $100 \%$ air saturation were measured without consuming oxygen during measurements [29]. The sensor foil spots were 
sanitized in $70 \%$ ethanol (Merck, Germany) and then calibrated by a two-point calibration using airsaturated water $\left(9.6 \mathrm{mg} / \mathrm{L} \mathrm{O}_{2}=100 \% \mathrm{O}_{2}\right)$ and $1 \%$ sodium sulfite $(\mathrm{w} / \mathrm{v})$ in water $\left(=0 \% \mathrm{O}_{2}\right)$ before mounting. With the Fibox 3 (Presens, Regensburg, Germany) and its algorithm it is possible to switch between different oxygen units for the oxygen concentration in water or in air. For our measurements we used the unit [\%], for which the equilibrium between oxygen in air and water was taken into account. Oxygen concentrations in the in- and outflow chamber were determined using the same optode technique.

Liquid sampling and cell counts. For taking water samples each of two stainless steel canulas (capillaries with an inner diameter of $0.001 \mathrm{~m}$, Ziemer-Chromatography, Germany) were inserted into the sand at distances $\mathrm{x}=0.1,0.2,0.3,0.45,0.6$ and $0.75 \mathrm{~m}$ from the inflow (ending in the CF $0-2 \mathrm{~cm}$ above the water table where the water saturation was still high enough to allow water sample removal) and into the in- and outflow chamber (Fig. 1). Duplicate water samples were slowly removed twice a week through the capillaries with $1 \mathrm{~mL}$ glass syringes (Fisher Scientific, Germany) to minimize disturbance of the flow field. The first $0.5 \mathrm{~mL}$ portion was discarded to avoid cross-contamination with previous samplings. The water samples were analyzed for dissolved organic carbon (DOC, $0.4 \mathrm{~mL}$ ), using a "High TOC Analyzer" (Elementar, Hanau, Germany) and for ammonia concentrations (0.5 mL) with a test kit of Dr. Lange (Berlin). Mean values and standard deviations were calculated and plotted for each experiment. Total cell counts per $\mathrm{mL}$ in the samples were determined by microscopy using only 5-6 $\mu \mathrm{L}$ according to [49] and $50 \mu \mathrm{l}$ were needed for life-dead staining.

Sand sampling and biomass quantification. Sand samples over the total height of the sand body were taken at the end of experimental phases I - V (see Table 1) to determine the cell mass per g dry sand as volatile solids (VS), presumably including up to $15 \%$ EPS [30]. No other insoluble organic compounds were expected after M535 medium flow-through. The DOC in the water film around the sand samples was removed by a washing step with de-inonized water. Sand profiles (approximately $10 \mathrm{~g}$ ) were removed at $\mathrm{x}=0.1,0.3$ and $0.5 \mathrm{~m}$ distance from the inflow chamber by pushing plastic tubes (0.015 $\mathrm{m}$ inner diameter) into the sand until the water table was reached. The sand columns covering the upper end of the aquifer and the CF were cut into pieces of respectively 0-2, 2-4, 4-6, 6-8, 8-10, 1013 and 13-16 cm length. Homogenized sand portions of $1.5 \mathrm{~g}$ were washed once with de-ionized water, filled into ceramic trays, dried for $24 \mathrm{~h}$ at $105{ }^{\circ} \mathrm{C}$, weighed and then heated to $550{ }^{\circ} \mathrm{C}$ for $5 \mathrm{~h}$ in a furnace to incinerate the organic material and to obtain the ash amount. By this procedure the dry mass of sand, moisture content and total volatile solids (bacteria + EPS) could be determined. Afterwards the holes in the sand of the SSC were carefully refilled with fresh sterilized sand.

Furthermore one $\mathrm{g}$ of each sand sample and $0.5 \mathrm{~mL}$ tap water were filled into $2 \mathrm{~mL}$ Eppendorf-cups and shaken vigorously for 10 seconds to suspend biofilm-forming bacteria. Quantitative dissolution of the biofilm $(>95 \%$ ) was checked by repeating this procedure. The cell density in each sand suspension was determined under the microscope and correlated with the VS per g dry sand. Subsequent samplings at the same flow distances $\mathrm{x}$ were performed $5 \mathrm{~cm}$ aside of former sampling positions.

Tracer experiments. Tracer experiments in the SSC were conducted before the experiment was started and after phases I - V (Table 1) using Bromide (Br-) as a conservative tracer [37]. Sterile solutions of the tracers were added directly into the medium of the inflow chamber by pulse release to reach a concentration of $10 \mathrm{mg} / \mathrm{L}$ at the start. The concentration of bromide in the inflow chamber, at the 6 different sampling points and in the outlet chamber was determined with an ICS-90 Ion chromatograph (Dionex, Germany). At the specific sampling positions in $0.025 \mathrm{~m}$ distance along the flow path $1 \mathrm{~mL}$ samples were taken approx. every $4 \mathrm{~h}$ to determine the tracer concentrations during water-flow. The focus was layed on the time at which the highest tracer concentration (peak) passed the respective sampling position. The concentrations $\mathrm{c}$ of bromide measured at the different sampling positions were plotted as ratio $\mathrm{c} / \mathrm{c}_{0}$, respectively, where $\mathrm{c}_{0}$ was the initial concentration of the tracer. By this procedure for one tracer experiment 7 breakthrough curves (one for each sampling point) were obtained, which were overlapping due to tailing. Every single curve revealed the specific point of time $t_{\max }$ at which the maximum tracer concentration (highest $c / c_{0}$ value) at each position passed the respective sampling position. With the time when maximum tracer concentrations reached the distance $\mathrm{x}$ from the inflow chamber and the medium flow parameters respective flow velocities $(\mathrm{v})$ in the sand of the SSC were determined. 


\section{$3 \quad$ Results and Discussion}

\subsection{Nutrient Consumption, Cell Concentrations and Biofilm Formation}

A long-term "groundwater" contamination experiment was conducted in the SSC with quartz sand imitating soil and with successively increasing/decreasing DOC concentrations and loads using an easily degradable organic medium (M535). The applied high DOC concentrations are typical for e.g. groundwater under sanitary landfills in the first years after closure or for aquifers under "industrially practiced" agriculture. P. fluorescens, a universal bacterium of soil and water was selected as a microorganism for investigation of DOC consumption and growth in the aquifer. Residual DOC concentrations after $0.1-0.9 \mathrm{~m}$ horizontal flow through the void volume of the sand during 5 experimental phases with stepwise increasing DOC supply (phases I - III) or with an increased flow rate (phases IV) are shown in Figure 2. Due to the relatively low flow rate of $120 \mathrm{~mL} / \mathrm{h}$ approximately 12$15 \%$ of the respective carbon sources of diluted M535 medium were consumed already in the $2.5 \mathrm{~L}$ inflow chamber, presumably by respiration with oxygen that slowly diffused through the surface film, formed by P. fluorescens aggregated cells. On average around $1.4 \times 10^{8}$ cells per $\mathrm{mL}$ and day grew in the inflow chamber, before medium and bacteria were transported into the adjacent sand volume. Following the flow path in sand the highest DOC consumption occurred in the CF directly above the saturated zone [27] within the first $0.3 \mathrm{~m}$ of horizontal flow. In this region flagellated P. fluorescens cells from the inflow chamber presumably were actively moving into the water-saturated part of the CF and above [31], where oxygen for respiration was replenished from air in the unsaturated sand volume. The $P$. fluorescens cells at least partially seemed to attach to the surface of sand grains and apparently dropped off their flagella, as for instance reported by [12] or as found by [34] in flow-through experiments with motile E. coli cells. The still high nutrient concentration allowed formation of a growing and stable biofilm on the sand grains. At the applied low flow rates within the first $0.2 \mathrm{~m}$ in flow direction the strongest filter/adsorption effect was seen. Such a behavior was, for instance, similarly observed by [14], [28] or [38] in column-filter and flow-through experiments.

After 8 weeks about $25 \%$ of the DOC $(98 \mathrm{mg} / \mathrm{L})$ of the medium was already consumed during the first $0.1 \mathrm{~m}$ flow and only another $25 \%$ during the following $0.8 \mathrm{~m}$ of horizontal flow through the sand. Sixteen After 16 weeks after start of the experiment, when the DOC concentration (196 mg/L) and the DOC load were doubled (Table 1), most of the DOC still was consumed in the first $0.1 \mathrm{~m}$ flow through the sand in the SSC (Fig. 2). After another 8 weeks (phase III) with another doubling of the DOC load at the same flow rate overall $80 \%$ of the DOC was degraded. About $20 \%$ of the DOC of the M535 medium was apparently not biodegradable under the conditions prevalent in the sand of the SSC. Although most of the DOC was degraded in the first $0.1 \mathrm{~m}$ flow through the sand in the SSC, a significant part of the DOC was degraded in the following $0.8 \mathrm{~m}$ later on (Fig. 2, phase III), indicating that bacterial activity was finally developed over the total distance of $0.9 \mathrm{~m}$ in flow direction. The degradation efficiency remained at about $80 \%$ when the flow rate was doubled (increasing shear forces) and the medium concentration was reduced to half (same DOC load, phase IV, Table 1). This indicated that mainly $P$. fluorescens cells, that were tightly attached to sand grains, may have contributed to degradation activity. Kinetics of bacterial sorption on soil particles seemed to depend on bacterial density in the water phase [6], cell motility [4] and [10], the size of soil particles [5] or on the flow velocity [9]. Hence, motile $P$. fluorescens cells, which have a high tendency for attachment on surfaces [24], [54], lost their motility after adsorption onto the sand grains or on already attached cells [12]. Adsorbed cells certainly formed a biofilm by excretion of EPS and the immobilized cells competed successfully with suspended cells for substrates. This may be the reason for the presence of much less suspended bacteria that were found later on in the pore water of the sand during phases IV and V (Fig. 3 ). The numbers of suspended cells were lower than those that were transported into the aquifer from the inflow chamber.

Suspended cells in the aquifer were not exactly imaging DOC consumption (Figures 2, 3). Only in the first 18 - 20 weeks (until midterm of phase III) the density of suspended cells in the pore water increased congruently with the DOC load and then decreased in phases IV and V to much lower cell numbers (Fig. 3). In parallel to this the biomass on the sand grains in the $\mathrm{CF}$ seemed to reach its maximal amount (Fig. 4), indicating a fully developed biofilm. Best growth conditions for P. fluorescens 
apparently existed in the aerobic region of the $\mathrm{CF}$ [32], a few $\mathrm{cm}$ above the water table, where enough moisture and plenty of carbon sources as well as oxygen were available. At more than $0.26 \mathrm{~m}$ height in the SSC (0.16 m CF height above the water table) towards the upper end of the CF a restricted carbon supply and/or a too low water activity at surplus oxygen availability may have limited growth.

As judged from the slow and incomplete DOC consumption at low initial DOC concentration of the M535 medium in phase I and even at a doubled DOC concentration in phase II, growth of $P$. fluorescens to high cell densities in the pore water of the $\mathrm{CF}$ and biofilm formation on the surface of sand grains was apparently very slow. In phase IV the DOC consumption remained high (Fig. 2), whereas the density of suspended cells decreased further (Fig. 3). According to Figures 2 and 4 only after more than 5 months of DOC supply, reaching up to $300 \mathrm{mg} / \mathrm{L}$ DOC in the water phase (in the beginning of phase III), the development of a steady state biofilm in the CF was apparently reached. This was in accordance with observations of [18], [19] and [20], who described slow biofilm development, requiring mutations for formation and excretion of extracellular polymeric substances (EPS) for successful immobilization of bacteria on solid particles in an oligotrophic groundwater aquifer.

Due to a relatively short doubling time of cells between the shortest 1.2 and maximally 5.3 hours and a flow velocity of only 0.19 to maximally $0.34 \mathrm{~cm} / \mathrm{h}$ in the $\mathrm{SSC}$ a fast washout of suspended and/or detached cells due to a turbulent water flow could be neglected. Never-the-less in phase V, when the medium flow rate and the DOC supply were both reduced again, at all sampling positions along the flow path roughly the same low number of $4.2 \times 10^{7}+/-1.2 \%$ suspended $P$. fluorescens cells per ml was determined (Fig. 3). Life-dead staining revealed that the majority of suspended cells (93-97\%) were alive. Even at the end of phase $\mathrm{V}$ almost no floc-like aggregates of cells (detached biofilm with dead cells) were found in the outflow chamber, indicating a stable, active biofilm on the sand grains at the available nutrient supply.

The mean ammonia concentrations in the aquifer after $0.1 \mathrm{~m}$ flow of medium in the SSC (Fig. S2) were $21+/-9 \mathrm{mg} / \mathrm{L}$ at the end of phase I, $52+/-10 \mathrm{mg} / \mathrm{L}$ at the end of phases II, IV and V and 103 $+/-16 \mathrm{mg} / \mathrm{L}$ at the end of phase III, with slightly increasing values in flow direction. NH4+ concentrations were always lower than one would expect after aerobic degradation of all available proteins or amino acids in the respective dilutions of the M535 medium. As expected, COD concentrations decreased with flow distance (data not shown), in parallel to the concentration of volatile solids (Fig. S3).

\subsection{Formation of a Biofilm on the Sand Grains}

The biomass on sand grains, determined as volatile solids (VS) per g dry sand as a measure of biofilm formation in the SSC increased with increasing DOC load and time. Hence, maximum biofilm formation at all heights of the $\mathrm{CF}$ in the SSC was found in phase IV, 6 months after start of the experiment (Fig. 4). Significantly lower DOC concentrations in the effluent of the SSC were found than before in phase III for the same DOC load (Fig. S5).

In phase II approximately the same amount of biomass per unit of sand was found up to $0.22 \mathrm{~m}$ height in the SSC (equivalent to $0.12 \mathrm{~m} \mathrm{CF}$ height above the water table), but the biomass continuously increased with higher DOC supply (Fig. 4). In the upper part of the CF at $0.27 \mathrm{~m}$ height above the water table in the SSC biomass on the sand grains was only detected after phase III. This may have been due to growth of the few bacteria that initially had moved up to this position, either actively by use of their flagella or passively by capillary forces. Growth could only start when the DOC supply through the water film on the sand grains was high enough in phase III. The increasing amount of biomass on the sand in the SSC above $0.22 \mathrm{~m}$ height in phases II - V may indicate a slowly developing biofilm by the initially only few $P$. fluorescens cells at increasing substrate diffusion/supply, presumably caused by evaporation of water. Excretion of an EPS matrix by the bacteria in the biofilm formed a hydrogel that captured enough moisture for growth. Finally a stable biofilm between 0.15 and $0.22 \mathrm{~m}$ height of the CF during phases III - V was formed (Fig. 4). Accumulation of P. fluorescens and EPS on the sand within the CF certainly had a direct impact on water retention, which would change transport and diffusion conditions for gases and liquids. [44] for instance has reported already that EPS from Pseudomonas species can increase the water storage capacity in porous media.

No significant increase of the biomass in the completely water-saturated sand or the almost watersaturated CF below $0.22 \mathrm{~m}$ height in the $\mathrm{SSC}$ was seen. When the flow rate of the medium was reduced 
to half at the same DOC concentration in phase V, thus bisecting the nutrient supply, less biomass on sand grains at every height of the $\mathrm{CF}$ was found. Substrate limitation apparently led to starvation of $P$. fluorescens cells in the biofilm and in consequence to a decrease of the biomass. Single cells presumably began to respire endogenously stored reserve products that have been accumulated during surplus substrate supply in phase III. Under starvation conditions the same numbers of living cells per g dry sand were found as during surplus substrate supply, but the biomass amount on the sand had decreased significantly. The highest biomass concentrations were found in the transition zone of the $\mathrm{CF}$ at 0.15 $0.20 \mathrm{~m}$ height above the water table (Fig. 4). After more than 24 weeks of continuous medium flow, in phase III $2.14+/-0.12 \mathrm{mg}$ biomass/g dry sand and after 38 weeks at the end of phase IV the highest amount of $2.77+/-0.14 \mathrm{mg}$ biomass/g dry sand in the $\mathrm{CF}$ at $0.17 \mathrm{~m}$ height above the water table in the SSC was determined (Fig. 4).

Finally, at a relatively high supply of biodegradable organic substances, emanating from the inflow chamber over the whole cross section degradation of DOC and biofilm formation was almost completed after only $0.9 \mathrm{~m}$ of horizontal flow through the sand in the SSC.

\subsection{Effect Influence of Biofilm Formation on Horizontal Water Flow}

In the first two weeks during start-up of the experiment in the SSC the medium flow velocity was restricted to only $0.336 \mathrm{~cm} / \mathrm{h}$ (approximately 11 days hydraulic retention time - HRT) to provide enough time for attachment of the inoculated P. fluorescens cells on the sand grains. Tracer experiments with bromide were conducted before inoculation and at the end of each experimental phase (Table 1) to determine the influence of biofilm formation on M535 medium flow characteristics through the saturated quartz sand. Eluted bromide concentrations in all experimental phases followed the typical shape of tracer break-through curves, as reported by [22]. The tracer experiments revealed a significant decrease of the mean average flow velocities through the aquifer and the CF of the sand in the SSC, compared to the initial flow rate through the sterile sand (Fig. 5). Consequently the HRT of the medium was slightly increasing when higher nutrient concentrations were supplied. Decreasing flow velocities in the SSC were in good agreement with the increasing biofilm formation on the sand grains (Fig. 4). Although biofilm formation in the water-saturated sand aquifer was much slower than in the CF, there was a significant increase with time of up to $15 \%$ (Fig. 4). Slightly decreasing flow rates predominantly were caused by narrowing of pores/clogging of pores within the first $0.2 \mathrm{~m}$ in flow direction, which led to a rise of the water table by maximally $5 \mathrm{~mm}$, in phase IV in the inflow chamber. Biofilm development on the sand grains in the CF during heavy contamination with biodegradable substances (e.g. by the M535 medium) had a long-lasting effect on flow-through parameters. Reduced flow velocities in the aquifer were persistent even when the pollution tailed off after phase IV and the cells in the biofilm starved, leading to a significant decrease of the biomass. As judged from the flow-through parameters, that "did not recover" under starvation conditions (Fig. 5), presumably due to a consistent volume of the biofilm (Fig. 5) and from the significant decrease of the biomass on the sand grains (Fig. S3) the EPS hydrogel kept its structure and persisted degradation. It can thus be assumed that the loss of biomass during starvation was due to starving cells, but that the slightly shrinking cell size apparently was of negligible relevance for the volume of the biofilm and for the flow behavior around biofilm-carrying sand grains in the aquifer. EPS seemed to maintain its volume for quite a while under starvation conditions, if the hydration state can be maintained. This is in contrary to its behavior at decreasing water potential, where the pore size of sand may change up to four orders of magnitude by a shrinking biofilm [43]. [2] or [3] has shown that strong biofilm formation, eventually in conjunction with entrapped metabolic gasses may finally cause biological clogging by reducing the void volume and in consequence the soil permeability. [48] found same results for biological clogging in sand filters. The same trend of a decreasing soil permeability was observed in the sand of the SSC (Fig. 5, columns I - V). The huge differences of the flow velocities for abiotic start conditions and "biotic" phases I - V with biofilm formation may indicate that even a faint, less than unicellular biofilm on soil particles can have a measurable effect of the horizontal flow-through behavior, even though biofilm formation is much more pronounced in the $\mathrm{CF}$. 


\subsection{Oxygen Concentrations in the Aquifer and the Capillary Fringe}

Biofilm formation on the sand of the SSC in the saturated zone and in particular in the CF led to high oxygen consumption [34] and due to the limited oxygen diffusion from the surface to a severe decrease of the oxygen concentrations in the CF (Fig. 6). Increasing nutrient concentrations in the horizontally flowing medium apparently not only moved through the water-saturated sand until they were metabolized but also diffused or were sucked up into the CF and were respired by P. fluorescens cells, embedded in the biofilm on the sand grains. Oxygen fluxes from above the CF towards the water table were not high enough to maintain constant oxygen profiles. In the course of the experiment the region with oxygen deficiency in the CF moved upwards over the whole length of the SSC due to increasing biofilm formation by $P$. fluorescens and the increasing respiratory activity in the CF. After phase I, for instance, at $\mathrm{X}_{\mathrm{P} 1}$ the transition of anaerobic to aerobic conditions was located approx. $3 \mathrm{~cm}$ higher than at $\mathrm{X}_{\mathrm{P} 2}$. At the highest substrate supply in phase III the anaerobic zone of the CF moved further upwards, as judged from the oxygen profiles (Figs. 6A, B). Surplus oxygen availability for respiration by P. fluorescens in the SSC started within the transition zone above $0.17 \mathrm{~m}$ height of the $\mathrm{CF}$ at $\mathrm{X}_{\mathrm{P} 1}$ and above $0.14 \mathrm{~m}$ height of the $\mathrm{CF}$ at $\mathrm{X}_{\mathrm{P} 2}$. At $\mathrm{X}_{\mathrm{P} 2}$ less oxygen was consumed due to less residual biodegradable DOC (Fig. 2) and significantly less biomass within the CF was found after $0.5 \mathrm{~m}$ flow distance (Fig. S3). At both probe positions $\mathrm{X}_{\mathrm{P} 1}$ and $\mathrm{X}_{\mathrm{P} 2}$ the oxygen concentration in the unsaturated $\mathrm{CF}$ region decreased with increasing nutrient concentrations in the aquifer, which resulted in a change of the oxygen gradient [23]. The lowest oxygen concentrations within the transition zone of the $\mathrm{CF}$ (presumably representing the highest oxygen consumption rates, in combination with a decreasing oxygen diffusion capacity) was monitored at the end of phase III at $\mathrm{X}_{\mathrm{P} 1}$, when the highest concentration of DOC was supplied. Oxygen consumption and the oxygen fluxes across the CF slightly decreased in phase $\mathrm{V}$, when DOC supply and the flow velocity were reduced.

\subsection{Variations of Temperature and Soil Moisture Tension}

At probe position $\mathrm{X}_{\mathrm{P} 1}$ in the SSC a tendency of a slightly increasing temperature within the watersaturated region and in the $\mathrm{CF}$ with increasing DOC in the horizontally flowing medium was observed (Fig. 7). The course of the temperature after phase III of the experiment at position $\mathrm{X}_{\mathrm{P} 2}$ was similar but minimally lower than at position $\mathrm{X}_{\mathrm{P} 1}$. The reason for this might be due to higher DOC concentrations in the substrate, allowing a higher bacterial activity in the first third of the container than later on and leading to little higher temperatures predominantly in the $\mathrm{CF}$. A really high temperature increase as for instance during aerobic composting (e. g. [41] and [47]) could not be expected due to the limiting substrate concentration for respiration and due to lacking insulation of the SSC. At both probe positions the mean temperatures in phases III and IV, when most substrate was available and metabolized by $P$. fluorescens in the sand of the SSC were significantly higher than in phase I, II and V, when less soluble organic material was supplied in the medium for respiration. An increased temperature in a sand box experiment of $0.5-1{ }^{\circ} \mathrm{C}$ during respiration of pollutants was also observed by [45]. In the SSC experiment the temperature changes resulted from bacterial heat production during respiration and presumably decreasing heat losses by a decreasing evaporation during accumulation of EPS. The extracellular polymeric substances (EPS) that are excreted by the bacteria for biofilm formation [19] and [20] may not only slow down evaporation but also act as insulation material and thus store heat from respiration, which leads to a slightly increased temperature in the SSC.

The soil moisture tension at positions $\mathrm{X}_{\mathrm{P} 1}$ (Fig. S4A) and $\mathrm{X}_{\mathrm{P} 2}$ (Fig. S4B) decreases only slightly, but significantly in phases III-V. It can be assumed that during these experimental phases the EPS, which was excreted by the $P$. fluorescens cells in the $\mathrm{CF}$, acted as a hydrogel and retained moisture. It was reported that EPS protected bacteria against dehydration and other negative factors [44], [26] and [20]. Therefore, due to an ongoing biofilm formation at high nutrient supply or after prolonged incubation time at low nutrient supply the water retention capacity within the CF (at least in the first third of the container) increased, as similarly shown by [11], and the soil moisture tension got less negative. It is generally assumed that this phenomenon was caused by microbial activity and that the impact was greater for the higher $\mathrm{CF}$ regions (tensiometers at $0.22,0.26$ or $0.30 \mathrm{~m}$ height, Fig. S5A, B). 


\subsection{Point Source Contamination of Cand in the SSC (Phase VI)}

During phase VI the horizontal flow of medium in the SSC was continued (Table 1) and a continuous point source contamination of the sand, $0.27 \mathrm{~m}$ above the water table $(0.05 \mathrm{~m}$ above the $\mathrm{CF})$, in $0.5 \mathrm{~m}$ distance from the inflow chamber was introduced with a trickling rate of $1 \mathrm{~mL} / \mathrm{h}$. None-diluted M535 medium that contained $9.8 \mathrm{~g} / \mathrm{L}$ easily biodegradable DOC was pumped into the sand to simulate for instance a leakage of a sewage pipe. The medium slowly percolated through the CF into the aquifer. Organic substances of the medium and oxygen from the air-filled void volume allowed respiration and growth of the $P$. fluorescens cells that had reached the unsaturated part of the CF so far and may have formed a faint biofilm already.

After maintaining the conditions of phase VI for one month a maximal residual DOC concentration of only $416+/-47 \mathrm{mg} / \mathrm{L}$ in samples taken at the water table in $0.1 \mathrm{~m}$ horizontal distance from the point source contamination ( $=0.6 \mathrm{~m}$ distance from the inflow chamber) was found (Fig. S5), which only was $4 \%$ of the applied concentration. The undiluted medium that trickled downwards the water table saturated the center of the plume and was diluted when it reached the water table by the horizontally flowing medium. Considering that in total $170 \mathrm{~mL}$ of M535 was pumped into the sand in one week, which passes an estimated water volume of $270 \mathrm{~cm}^{3}\left(10\right.$ (length) $\times 27$ (height) $\times 2$ (width) $\mathrm{cm}^{3} \times 50 \%$ Ø-saturation) we expected an increasing DOC in the aquifer after 1.5 weeks. Figure S5 shows that this assumption was acceptable. However, beside dispersion and dilution of the DOC from the point source application during percolation towards the water table in the SSC increasing microbial activity in the contamination plume within the $\mathrm{CF}$ and later on during horizontal flow in the sand towards the outflow chamber, may explain the relatively low maximum DOC concentration in SSC effluent after 4 weeks (Fig. S5). After 10 weeks at the end of phase VI DOC concentrations in the medium that reached the outflow chamber (mixture of vertical point source contamination and horizontally flowing medium) were as low as $97+/-25 \mathrm{mg} / \mathrm{L}$. High removal efficiencies of pollutants after a very slow formation of a stable biofilm in sand filters were also reported for pathogenic bacteria (e. g. [8] and [38]), phenol [52] or biocides [7] from contaminated water.

If compared with the findings in sand filters the amount of suspended cells in the plume of the SSC during point source contamination was very low. A stable, tightly attached biofilm on the sand grains was apparently formed in the contamination plume and a biomass amount of $10.5-12.8 \mathrm{mg}$ VS per $\mathrm{g}$ dry sand was determined in the direct neighborhood of the point contamination source. In the SSC numbers of suspended cells at $\mathrm{x}=0.6 \mathrm{~m}$ increased only from $4.3 \times 10^{7}$ to $6.6 \times 10^{7}$ cells $/ \mathrm{mL}$ during one month of point source contamination. These numbers were similar to those detected within the first 0.1 - $0.2 \mathrm{~m}$ in phase III with almost $0.4 \mathrm{~g} / \mathrm{L}$ DOC (Fig. 3). After 6 weeks of point source contamination the amount of suspended cells in the aquifer at the outflow decreased. The cell numbers were stable after 2 months, ranging from $4.2 \times 10^{7}$ to $5.6 \times 10^{7}$ cells $/ \mathrm{mL}$.

Oxygen measurements across the CF in the SSC during phase VI revealed that the oxygen profile downstream of the contamination source was significantly changed. Oxygen concentrations in the transition region of the $\mathrm{CF}$ at $\mathrm{X}_{\mathrm{P} 2}$ (in $0.25 \mathrm{~m}$ distance from the point source contamination) were much lower than above in the plume, presumably because of a sufficient oxygen re-saturation by diffusion from the surrounding unsaturated sand volume. On the other hand the EPS hydrogel matrix of the specially expanding biofilm in conjunction with a decreasing void volume aggravates vertical oxygen diffusion into the CF towards the aquifer [1] and [40] and horizontal oxygen diffusion into the center of the contamination plume.

\section{Conclusions}

Biofilm formation by $P$. fluorescens in $0.212 \mathrm{~m}^{3}$ water-saturated quartz sand and in its capillary fringe (CF) under flow-through conditions, and the consequences for hydrological and physical soil parameters were investigated in a stainless steel container (SSC). Continuously increasing DOC concentrations of M535 medium with up to $0.395 \mathrm{~g} / \mathrm{L}$ were pumped horizontally through the sand aquifer. Finally, after a stable biofilm has been formed in the water-saturated sand and it's CF at a medium flow velocity of $0.336 \mathrm{~cm} / \mathrm{h}$, a massive continuous point source contamination above the $\mathrm{CF}$, with a DOC concentration of $9.8 \mathrm{~g} / \mathrm{L}$ at a trickling rate of $1 \mathrm{~mL} / \mathrm{h}$ was carried out. Physical soil parameters such as soil moisture tension, temperature, the average flow velocity and the oxygen concentration were determined in 
addition to analyses of suspended and immobilized cells. Increasing cell retention and a strong biofilm formation on sand grains, predominantly within the first $0.3 \mathrm{~m}$ of the SSC, was observed after months. Oxygen profiles, the temperature within the $\mathrm{CF}$ and the flow velocity in the aquifer were influenced by suspended and particularly immobilized P. fluorescens cells. Organic substances in infiltrated medium from above the $\mathrm{CF}$ had little influence on the water-saturated aquifer since most of the organic substances were either degraded by the $P$. fluorescens biofilm in the upper, air-saturated CF region or diluted in the flow path towards the water table and during horizontal flow in the water-saturated sand. Following general conclusions could be drawn:

1. A stepwise increase of easily biodegradable organic contaminants in the water phase of a homogeneous sand under flow through conditions led to a slow formation of a stationary biofilm over several months in the water-saturated sand and its CF. More biofilm was formed on sand grains in the vicinity of the contamination source. Biofilm formation was accelerated at concentrations of $>200 \mathrm{mg} / \mathrm{L}$ DOC in the aquifer, but continued over months. When the biofilm was finally established, lowest numbers of suspended bacteria were present in the water phase.

2. Even when relatively high concentrations of biodegradable substances of $\geqslant 395 \mathrm{mg} / \mathrm{L}$ were present in the water, degradation of around $82 \%$ of the organic substances after $0.9 \mathrm{~m}$ of horizontal flow away from a contamination source was achieved, when a steady state biofilm on the sand grains was finally developed. Only about $4 \times 10^{7} \mathrm{P}$. fluorescens cells $/ \mathrm{mL}$ were present in suspension. Since the amount of suspended bacteria and the DOC concentration in effluent of the SSC decreased simultaneously with time at a constant medium flow rate, most of the DOC must have been degraded by immobilized $P$. fluorescens cells in a stationary biofilm.

3. Best growth conditions for aerobic and facultative anaerobic $P$. fluorescens cells apparently existed in the transition zone of the CF. Biomass concentrations of $2.8 \mathrm{mg}$ volatile solids (VS) were found in the unsaturated transition zone of the $\mathrm{CF}$ at $0.1 \mathrm{~m}$ distance from the contamination source and still 1.6-1.9 mg VS per $\mathrm{g}$ dry sand in the almost saturated CF directly above the water table after highest DOC supply.

4. Oxygen concentrations and soil moisture tension in the transition zone of the $\mathrm{CF}$ were significantly reduced at DOC concentrations above $0.2 \mathrm{~g} / \mathrm{L}$ in the aquifer that allowed a high respiration activity and good bacterial growth with EPS excretion.

5. At increasing nutrient supply for a stationary biofilm in the CF heat release during respiration in the non-insulated SSC may increase the sand temperature by $0.5{ }^{\circ} \mathrm{C}$.

6. Water permeability in the aquifer successively decreased with ongoing biofilm formation over several months. The average flow velocity in the SSC decreased from initially $0.336 \mathrm{~cm} / \mathrm{h}$ to finally $0.187 \mathrm{~cm} / \mathrm{h}$, due to biological "narrowing of pores" in the flow paths.

7. A massive point source contamination above the $\mathrm{CF}$ with a low flow rate of $1 \mathrm{~mL} / \mathrm{h}$, trickling through the quartz sand and simulating for instance a leakage of a wastewater pipe, resulted in very high biomass concentrations of $10.5-12.8 \mathrm{mg}$ VS per g dry sand in the neighborhood of the infiltration point, but did not drastically influence the more distant aquifer.

Acknowledgment. We thank Deutsche Forschungsgemeinschaft (DFG) for financial support of the research group FOR 831 and especially for funding the central experiment, which allowed design and construction of the three-dimensional SSC with all the analytical devices for online measurements. We thank Mr. Bonefas for excellent assistance during the experiments. Furthermore, we thank all members of the research group "Dynamic capillary fringes - a multidisciplinary approach (DyCap)" for helpful discussions during the project running time. Special thanks go to our colleagues of the interdisciplinary center for scientific computing at the University of Heidelberg for raw data analysis and transformation.

\section{References}

1. Affek, H.P., Ronen, D., Yakir, D., 1998. Production of CO2 in the capillary fringe of a deep phreatic aquifer. Water Resources Research 34, 989-996.

2. Avnimelech, Y. and Nevo, Z., 1964. Biological clogging of sands. Soil Sciences. 
3. Baveye, P., Vandevivere, P., Hoyle, B.L., DeLeo, P.C., de Lozada, D.S., 1998. Environmental impact and mechanisms of the biological clogging of saturated soils and aquifer materials. Critical Reviews in Environmental Science and Technology 28, 123-191.

4. Becker, M.W., Collins, S.A., Metge, D.W., Harvey, R.W., Shapiro, A.M., 2004. Effect of cell physicochemical characteristics and motility on bacterial transport in groundwater. Journal of Contaminant Hydrology 69, 195213.

5. Bengtsson, G. and Ekere, L., 2001. Predicting sorption of groundwater bacteria from size distribution, surface area, and magnetic susceptibility of soil particles. Water Resources Research 37(6), 1795-1812.

6. Bengtsson, G. and Lindqvist, R., 1995. Transport of soil bacteria controlled by density-dependent sorption kinetics. Water Resources Research 31, 1247-1256.

7. Bester, K., Banzhaf, S., Burkhardt, M., Janzen, N., Niederstrasser, B., Scheytt, T., 2011. Activated soil filters for removal of biocides from contaminated run-off and waste-waters. Chemosphere 85, 1233-1240.

8. Bomo, A.-M., Ekeberg, D., Stevik, T.K., Hanssen, J.F., Frostegard, A., 2004. Retention and removal of the fish pathogenic bacterium Yersinia ruckeri in biological sand filters. Journal of Applied Microbiology 97, 598-608.

9. Camesano, T.A. and Logan, B.E., 1998. Influence of fluid velocity and cell concentration on the transport of motile and non-motile bacteria in porous media. Environmental Science and Technology 32, 1699-1708.

10.Camper, A.K., Hayes, J.T., Sturman, P.J., Jones, W.L., Cunningham, A.B., 1993. Effects of motility and adsorption rate coefficient on transport of bacteria through saturated porous media. Applied and Environmental Microbiology 59, 3455-3462.

11.Chenu, C., 1993. Clay- or sand-polysaccharide associations as models for the interface between micro-organisms and soil: water related properties and microstructure. Geoderma 56, 143-156.

12.Choy, W.-K., Zhou, L., Syn, Ch.K.-Ch., Zhang, L.-H., Swarup, S., 2004. MorA Defines a New Class of Regulators Affecting Flagellar Development and Biofilm Formation in Diverse Pseudomonas Species. J. Bacteriol. 2004, 186(21):7221-7228. DOI:16.1128/JB 126.21.7221-7228 2004. http://jb.asm.org/content/186/21/7221

13.Costerton, J.W., Stewart, P.S., Greenberg E.P., 1999. Bacterial biofilms: A common cause of persistent infections. Science 284, 1318-1322.

14.Davidson, J., Helwig, N., Summerfelt, S.T., 2008. Fluidized sand biofilters used to remove ammonia, biochemical oxygen demand, total coliform bacteria, and suspended solids from an intensive aquaculture effluent. Aquacultural Engineering 39, 6-15.

15.DIN 1998. Baugrund - Untersuchung von Bodenproben; Bestimmung des Wasserdurchlässigkeitsbeiwerts - Teil 1 : Laborversuche. Beuth-Verlag, 1998.

16.Dutta, T., Carles-Brangarí, A., Fernàndez-Garcia, D., Rubol, S., Tirado-Conde, J., Sanchez-Vila. X., 2015. Vadose zone oxygen (O2) dynamics during drying and wetting cycles: An artificial recharge laboratory experiment. J. Hydrology 527, 151-159.

17.Fierer, N., Schimel, J.P., Holden, P.A., 2003. Variations in microbial community composition through two soil depth profiles. Soil Microbiol. and Biochem. 35, 167-176.

18.Flemming, H.-C. and Wingender, J., 2001a. Biofilme - Die bevorzugte Lebensform der Bakterien. Biologie in unserer Zeit (Nr.3), 169-180.

19.Flemming, H.-C. and Wingender, J., 2001b. Relevance of microbial extracellular polymeric substances (EPSs) Part I: structural and ecological aspects. Water Science and Technology 43, 1-8.

20.Flemming, H.-C., Wingender J., 2010. The biofilm matrix. Nature Reviews Microbiology 8, 623-633.

21.Gallert, C. and Winter, J., 2013. Verfahren der Abwasserreinigung. In: Industrielle Mikrobiologie. H. Sahm, G. Antranikian, K.-P. Stahmann, R. Takors (eds.), Springer Spektrum, Berlin Heidelberg 2013.

22.Grindrod, P., Edwards, M.S., Higgo, J.J.W., Williams, G.M., 1996. Analysis of colloid and tracer breakthrough curves. J. Contaminant Hydrol. 21, 243-253.

23.Haberer, C.M., Rolle, M., Cirpka, O.A., Grathwohl, P., 2012. Oxygen transfer in a fluctuating capillary fringe. Vadose Zone Journal 11, no. 3. DOI:10.2136/vzj2011.0056.

24.Hinsa, S.M., Espinosa-Urgel. M., Ramos, J.L., O'Toole. G.A., 2003. Transition from reversible to irreversible attachment during biofilm formation by Pseudomonas fluorescens WCS365 requires an ABC transporter and a large secreted protein. Mol. Microbiol. 49:905-918. doi:10.1046/j.1365-2958.

25.Holden, P. A., and Fierer N. 2005. Microbial Processes in the Vadose Zone. Vadose Zone J. 4:1-21. doi:10.2136/vzj2005.0001. 
26.Holden, P.A., Hunt, J.R., Firestone, M.K., 1997. Toluene diffusion and reaction in unsaturated Pseudomonas putida biofilms. Biotechnology and Bioengineering 56, 656-670.

27.Hron, P., Jost, D., Bastian, P., Gallert, C., Winter, J., Ippisch, O., 2015. Application of reactive transport modeling to growth and transport of microorganisms in the capillary fringe. Vadose Zone Journal, in press. doi:10.2136/vzj2014.07.0092.

28.Hua, J., An, P., Winter, J., Gallert, C., 2003. Elimination of COD, microorganisms and pharmaceuticals from sewage by trickling through sandy soil below leaking sewers. Water Research 37, 4395-4404.

29.Huber, C., and Krause, C., 2006. Instruction Manual Fibox3. PreSens GmbH, Regensburg, Germany, 85p.

30.Jiao, Y., Cody, G.D., Harding, A.K., Wilmes, P., Schrenk, M., Wheeler, K.E., Banfield, J.F., Thelen, M.P., 2010. Characterization of Extracellular Polymeric Substances from Acidophilic Microbial Biofilms. Applied and Environmental Microbiology 76 (9), 2916-2922.

31.Jost, D., Winter, J., Gallert, C., 2010. Distribution of aerobic motile and non-motile bacteria within the capillary fringe of silica sand. Water Research 44, 1279-1287.

32.Jost, D., Winter, J., Gallert, C., 2011. Water and oxygen dependence of Pseudomonas putida growing in silica sand capillary fringes. Vadose Zone Journal 10, 532-540.

33.Jost, D., Winter, J., Gallert, C., 2015a. Non-invasive quantification of GFP-labeled Escherichia coli in the capillary fringe by fluorescence intensity. Vadose Zone Journal 14(5), DOI:10.2136/vzj2014.03.0028.

34.Jost, D., Haberer, C.M., Grathwohl, P., Winter, J., Gallert, C., 2015b. Oxygen transfer in a fluctuating capillary fringe: Impact of microbial respiratory activity. Vadose Zone Journal 14(5), doi:10.2136/vzj2014.04.0039.

35.Klimant, I., Meyer, V., Kuhl, M., 1995. Fiber-optic oxygen microsensors, a new tool in aquatic biology. Limnology and Oceanography 40: 1159-1165.

36.Klinge, K., 1960. Differential techniques and methods of isolation of Pseudomonas. Journal of Applied Bacteriology 23(3): 442-462.

37.Levy, B.S. and Chambers, R.M., 1987. Bromide as a conservative tracer for soil-water studies. Hydrological Processes 1: 385-389.

38.Li, J., McLellan, S., Ogawa, S., 2006. Accumulation and fate of green fluorescent labeled Escherichia coli in laboratory-scale drinking water biofilters. Water Research 40, 3023-3028.

39.Liebsch, G., Klimant, I., Wolfbeis, O.S., 1999. Luminescence lifetime temperature sensing based on sol-gels and poly(acrylonitrile)s dyed with Ruthenium Metal-Ligand Complexes. Advanced Materials 11, no. 15: 1296-1299.

40.Maier, U., Rügner, H., Grathwohl, P., 2007. Gradients controlling natural attenuation of ammonium. Applied Geochemistry 22, 2606-2617.

41.Nell, J.H. and Wiechers, S.G., 1978. High-temperature composting. Water SA 4, 203-212.

42.Nijburg, J.W., Gerards, S., Laanbroek, H.J., 1998. Competition for nitrate and glucose between Pseudomonas fluorescens and Bacillus licheniformis under continuous or fluctuating anoxic conditions. FEMS Microbiology Ecology 26, 345-356.

43.Or, D., Phutane, S., Dechesne A., 2007. Extracellular Polymeric Substances Affecting Pore-Scale Hydrologic Conditions for Bacterial Activity in Unsaturated Soils. Vadose Zone Journal 6, 298-305.

44.Roberson, E.B. and Firestone, M.K., 1992. Relationship between desiccation and exopolysaccharide production in a soil Pseudomonas sp. Applied and Environmental Microbiology 58, 1284-1291.

45.Rubol, S., Freixa, A., Carles-Brangarí, A., Fernàndez-Garcia, D., Romaní, A.M., Sanchez-Vila, X., 2014. Connecting bacterial colonization to physical and biochemical changes in a sand box infiltration experiment. J. Hydrology 517, 317-327.

46.Sandhya, V., Ali, Sk. Z., 2015. The Production of Exopolysaccharide by Pseudomonas putida GAP_P45 under Various Abiotic Stress Conditions and Its Role in Soil Aggregation. Microbiology 84, 512-519.

47.Sikora, L.J. and Sowers, M.A., 1985. Effect of temperature control on the composting process. Journal of environmental quality 14, 434-439.

48.Spychała, M. and Błazejewski, R., 2003. Sand filter clogging by septic tank effluent. Water Science and Technology 48, 153-159.

49.Taylor, J.P., Wilson, B., Mills, M.S., Burns, R.G., 2002. Comparison of microbial numbers and enzymatic activities in surface soils and subsoils using various techniques. Soil Biology \& Biochemistry 34:387-401. 
50.Thullner, A., Mauclaire, L., Schroth, M.H., Kinzelbach, W., Zeyer, J., 2002. Interaction between water flow and spatial distribution of microbial growth in a two dimensional flow field in saturated porous media. J. Conamination Hydrology 58, 169-189.

51.Warkentin, M., Freese, H.M., Karsten, U., Schumann, R., 2007. New and fast method to quantify respiration rates of bacterial and plankton communities in freshwater ecosystems by using optical oxygen sensor spots. Applied and Environmental Microbiology 73: 6722-6729.

52.Welz, P.J., Ramond, J.-B., Cowan, D.A., Burton, S.G., 2012. Phenolic removal processes in biological sand filters, sand columns and microcosms. Bioresource Technology 119, 262-269.

53.Whitman W.B., Coleman D.C., Wiebe W.J., 1998. Prokaryotes: The unseen majority. PNAS 95 (12), 6578-6583.

54.Yousef-Coronado, F., Travieso, M.L., Espinosa-Urgel, M., 2008. Different, overlapping mechanisms for colonization of abiotic and plant surfaces by Pseudomonas putida. FEMS Microbial Letters 288(1), 118-124. DOI: http://dx.doi.org/10.1111/j.1574-6968.2008.01339.x

\section{Appendix: Figures}

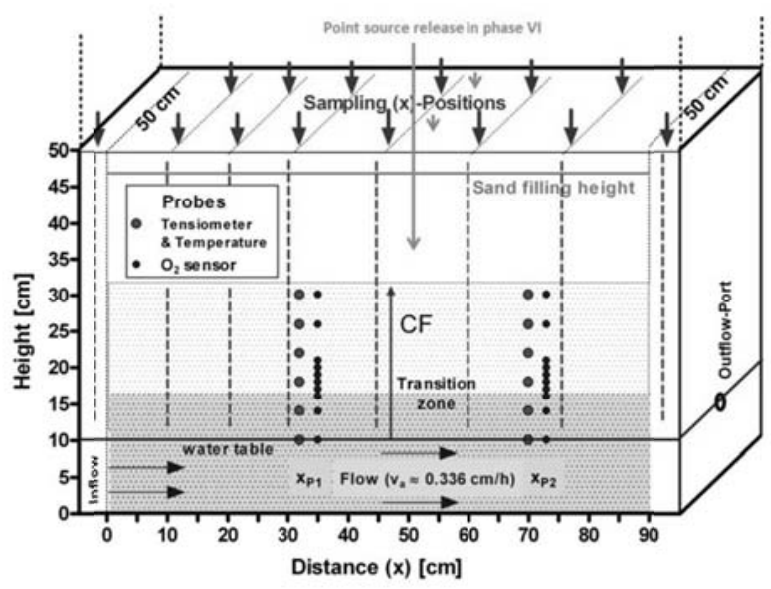

Figure 1. Scheme of the stainless steel container (SSC). Red dots at positions $X_{P 1}$ and $X_{P 2}$ indicate positions of tensiometers and PT100 temperature probes and blue dots those of oxygen sensors. Tube positions for groundwater sampling are marked with green dashed lines and arrows on top of the SSC. The height of the capillary fringe (CF) is indicated by a black arrow on the front panel and the position of point source release in phase VI of the experiment is marked with orange arrows. 


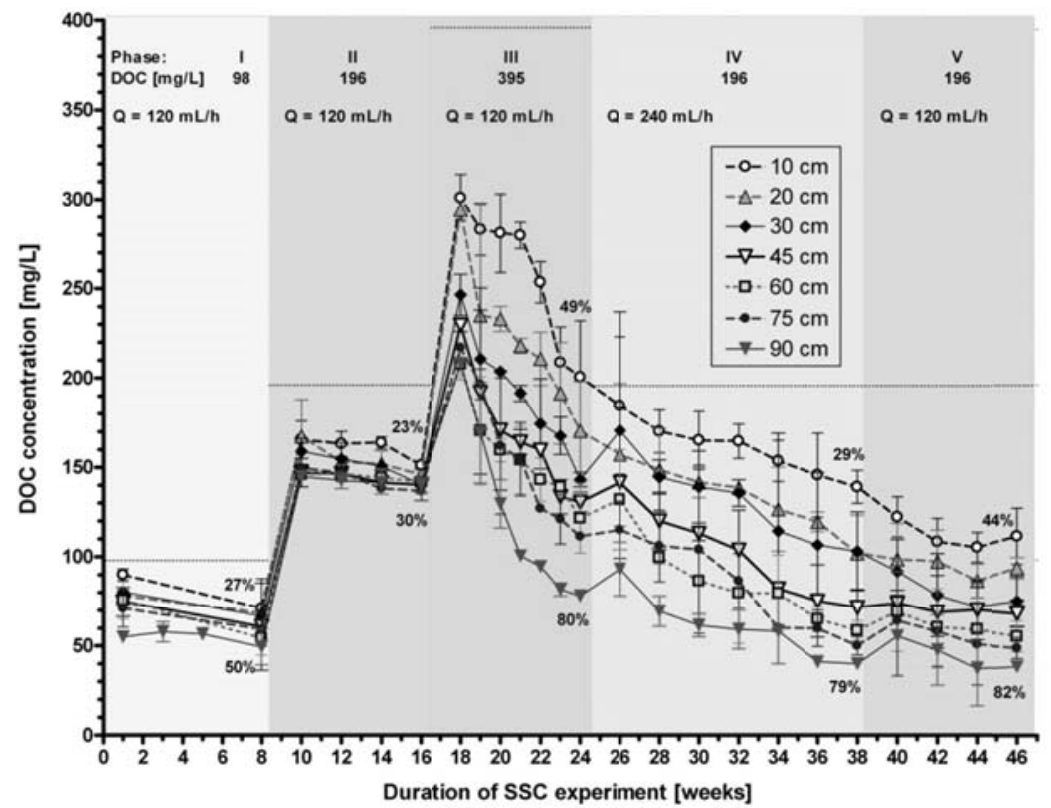

Figure 2. Dissolved organic carbon (DOC) concentrations in the aquifer of the SSC $(\mathrm{mg} / \mathrm{L}+/$ - standard deviation, $\mathrm{n}=4)$. DOC was determined in the CF $0.02 \mathrm{~m}$ above the water table once a week during phases I - V of the container experiment at $0.1,0.2,0.3,0.45,0.6,0.75$ and $0.9 \mathrm{~m}$ distance from the inflow chamber (see Fig. 1). Dashed lines mark the DOC concentrations in the inflowing medium during each phase, whereas the respective concentration in the inflow chamber was 10-15\% lower. DOC consumptions [\% of inflow concentration] at the end of each phase after 0.1 and $0.9 \mathrm{~m}$ horizontal flow through the sand are indicated by the $\%$-values above and below the curves, respectively.

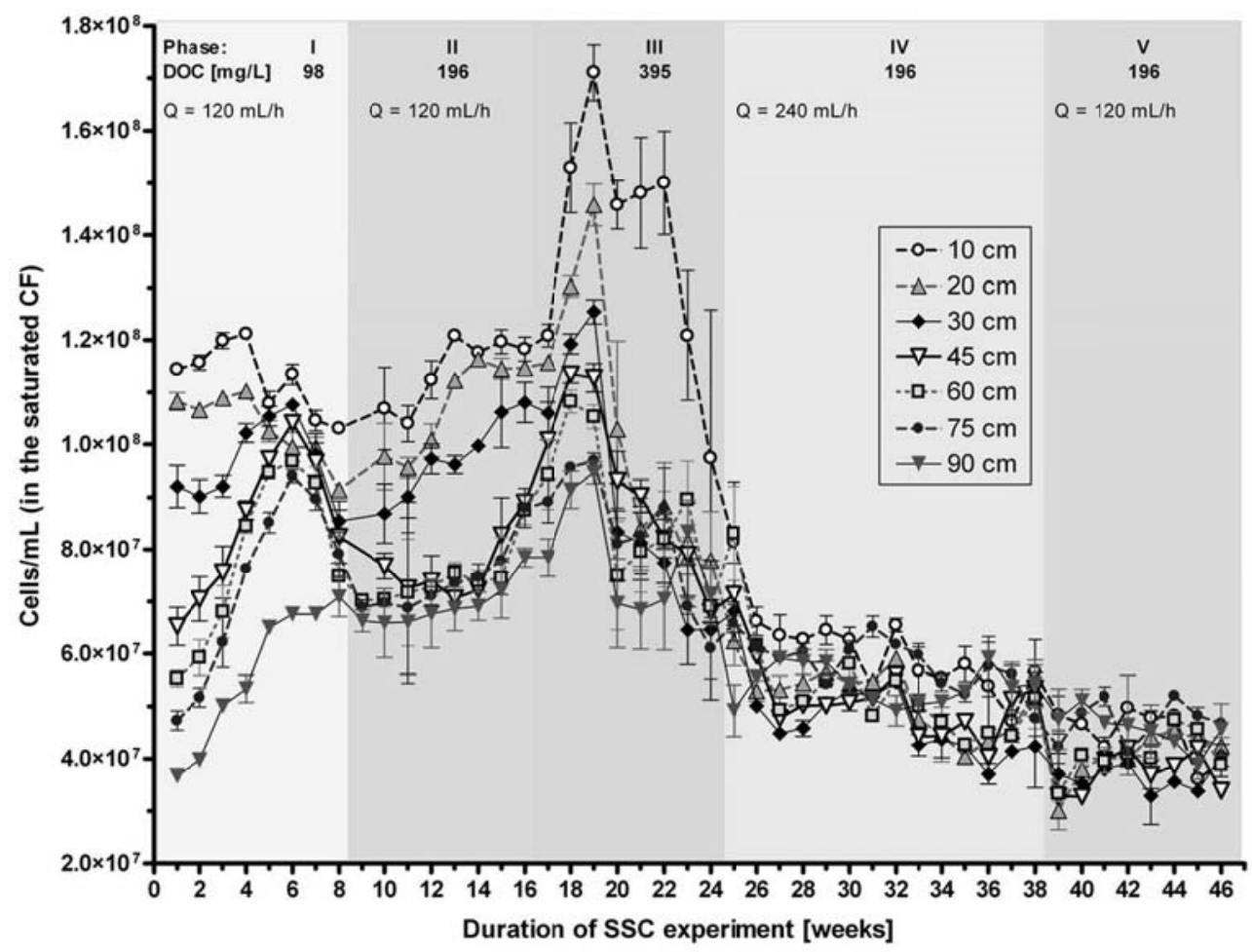

Figure 3. Cell counts in the almost saturated CF $[$ cells $/ \mathrm{mL}](+/-$ standard deviation, $\mathrm{n}=8) 0.02 \mathrm{~m}$ above the water table in the SSC. Cell densities in liquid samples that were taken at 0.1, 0.2, 0.3, 0.45, 0.6, 0.75 and $0.9 \mathrm{~m}$ distance from the inflow chamber of the SSC were determined by counting with a Zeiss phasie contrast microscope. 


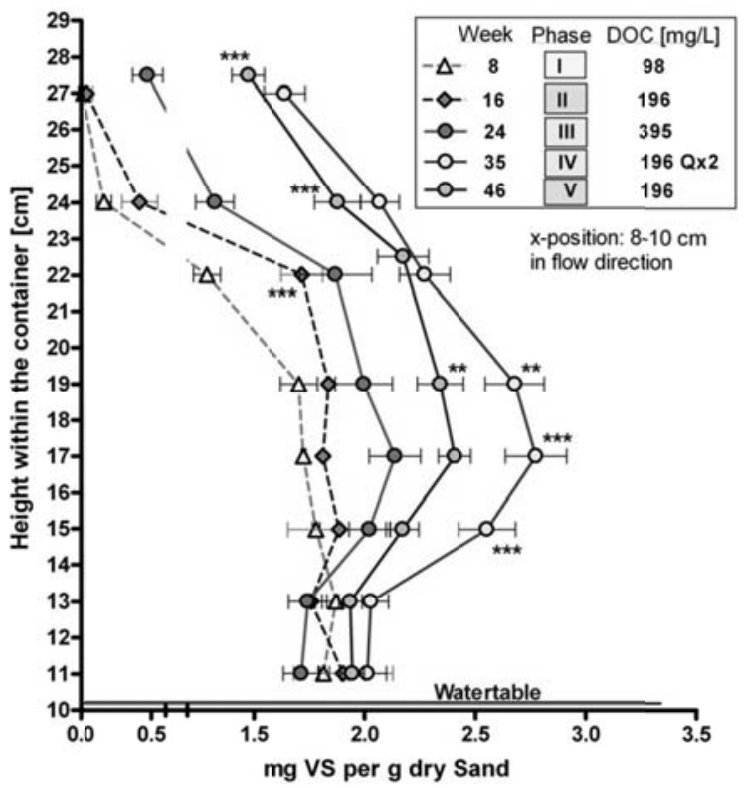

Figure 4. Amount of volatile solids (mg VS per $g$ dry sand $+/$ - standard deviation, $n=4$ ) on sand grains within the SSC that were taken from different heights of the $\mathrm{CF}$ at $\mathrm{x}=8-10 \mathrm{~cm}$ distance from the inflow chamber. Experimental phases and respective substrate supply or changes of the flow rate $\mathrm{Q}$ are indicated in the legend. ** and $* * *$ indicate significant differences $(\mathrm{p}<0.001 \& \mathrm{p}<0.01)$ at the same height as compared to the previous phase (Two-Way ANOVA). Values for phase VI of the experiment were not significantly different from those in phase $\mathrm{V}$.

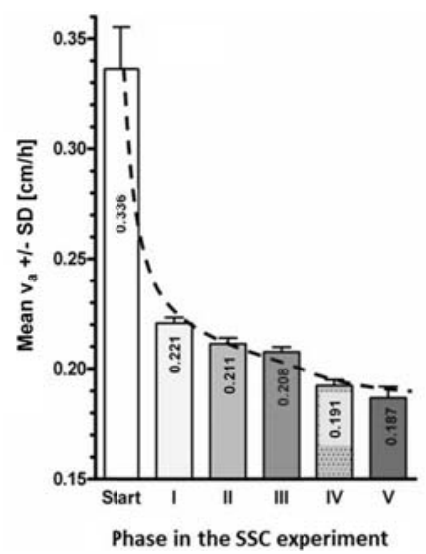

Figure 5. Mean average flow velocities va $(+/-$ standard deviation $(\mathrm{SD}), \mathrm{n}=7)$ at the end of each phase of the SSC experiment. For better comparison va values of phase IV (flow rate doubled at half substrate concentration) were divided by 2. Values based on tracer experiments with bromide. 

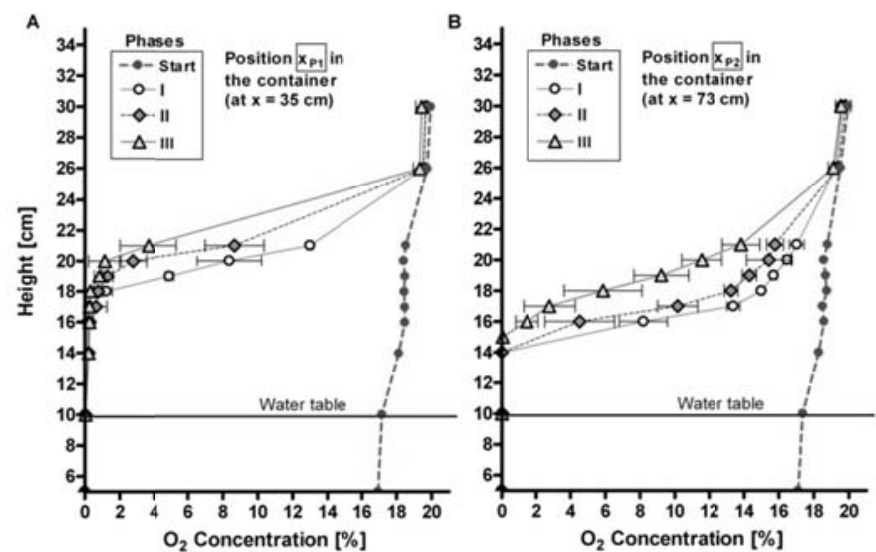

Figure 6. Mean oxygen concentration (\% of air saturation $+/-$ standard deviation, $n=10)$ at different heights in the sand of the SSC at $0.35 \mathrm{~m}$ (position XP1, A) and $0.73 \mathrm{~m}$ (positions XP2, B) distance from the inflow chamber, respectively. Results represent oxygen concentrations at the end of phase I - III (see Table 1) of the SSC experiment, with 20.95 vol. \% oxygen as maximum in air.

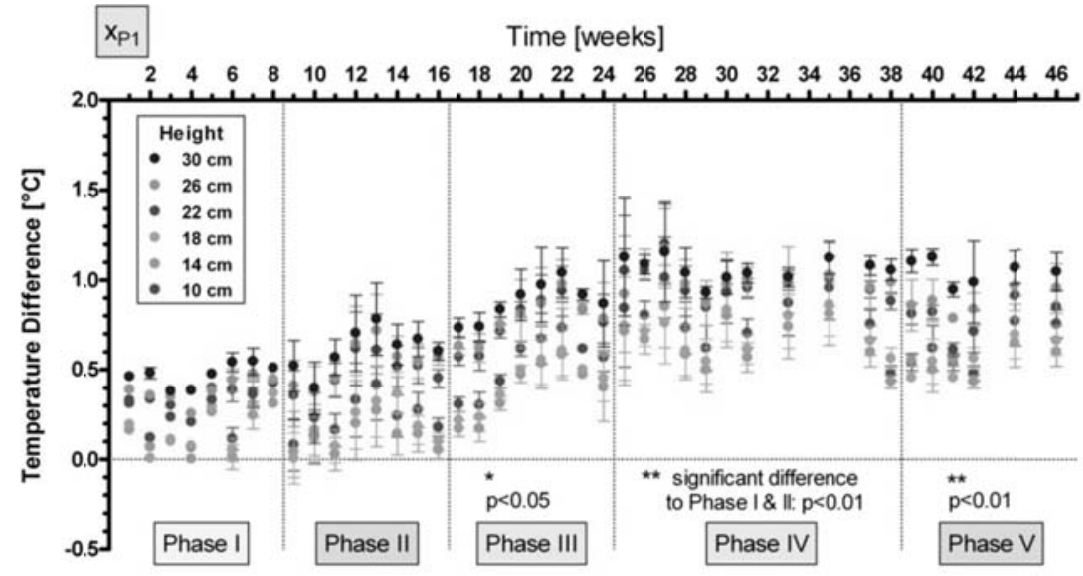

Figure 7. Temperature difference compared to the room temperature $(+/-$ standard deviation, $n=10)$ of the sand in different heights of the SSC at position XP1, $0.35 \mathrm{~m}$ away from the inflow chamber. 


\section{Appendix: Figures as Supplementary Material}

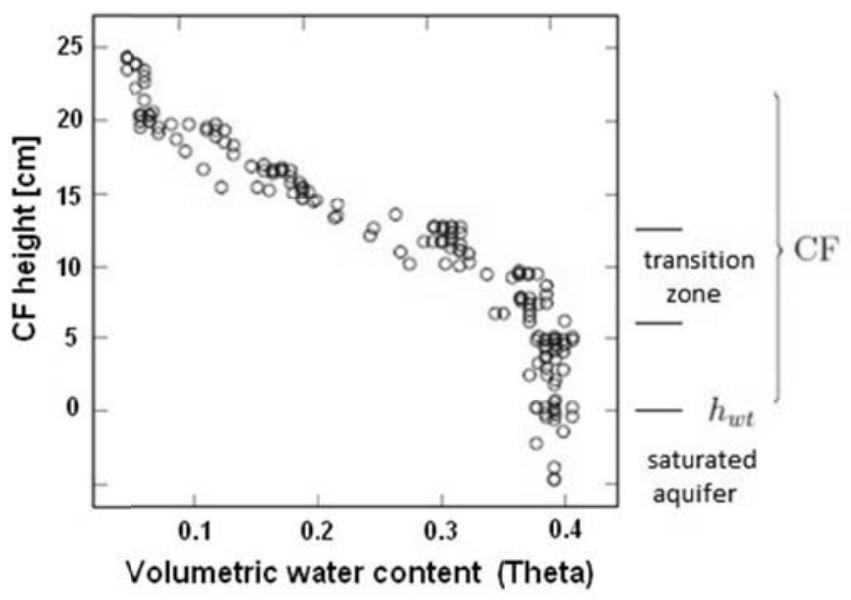

Figure S1. Water retention curve for sterilized quartz sand (grain size diameter: $2 \times 10-4-6 \times 10-4 \mathrm{~m}$, porosity: $\mathrm{n}=$ 0.38) used in the SSC (abiotic conditions). The water content (Theta) was determined gravimetrically after disassembling flow-through Hele-Shaw cells filled with the same sand to estimate the total $\mathrm{C} F$ height.

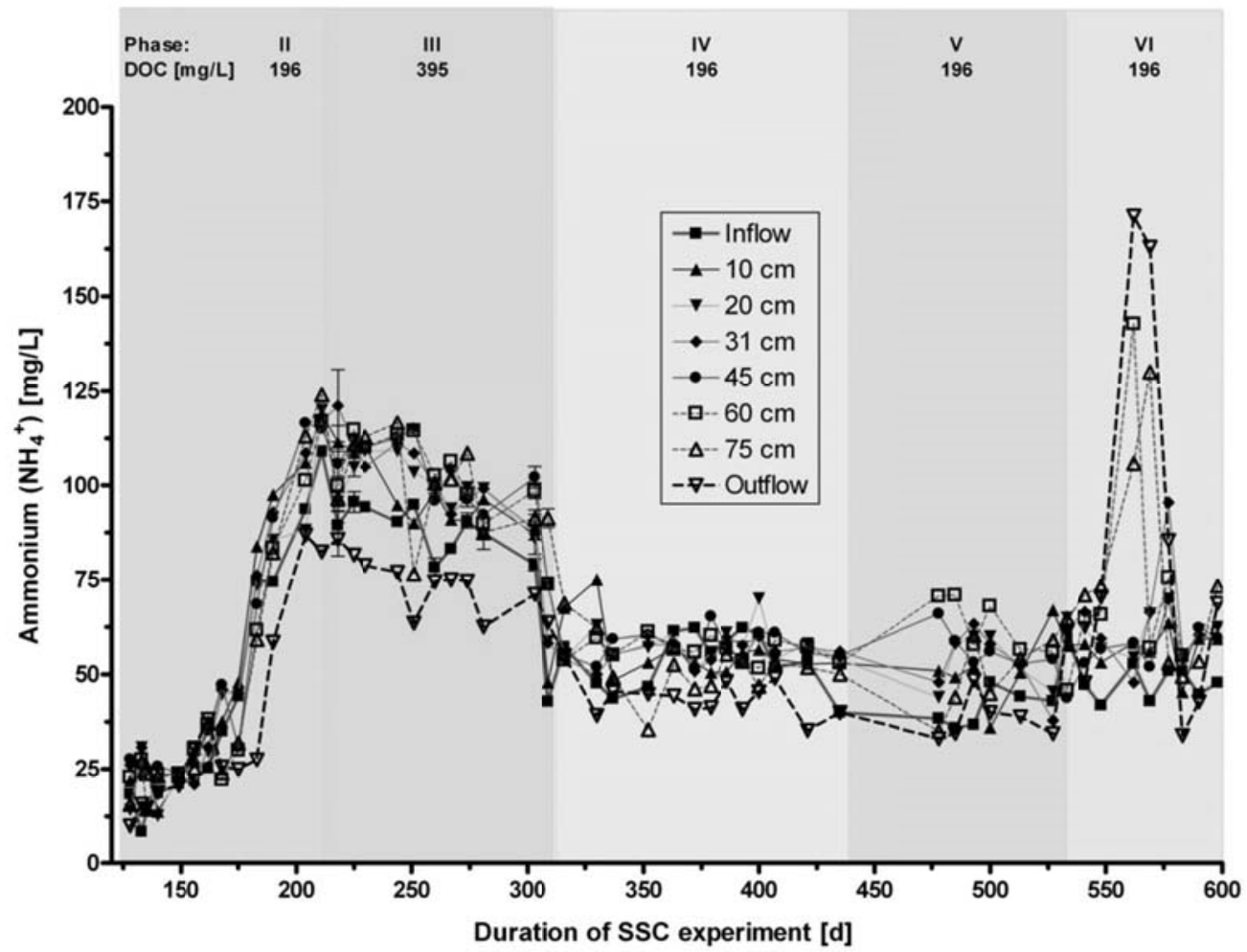

Figure S2. Ammonium (NH4+) concentrations in the aquifer of the SSC (mg/L +/- standard deviation, $\mathrm{n}=4)$. $\mathrm{NH} 4+$ was determined in the CF $0.02 \mathrm{~m}$ above the water table once a week during phases I - VI of the container experiment at $0.1,0.2,0.3,0.45,0.6,0.75$ and $0.9 \mathrm{~m}$ distance from the inflow chamber (see Fig. 1). The initially inoculated DOC concentration for each experimental phase is given on top of the graphic. 

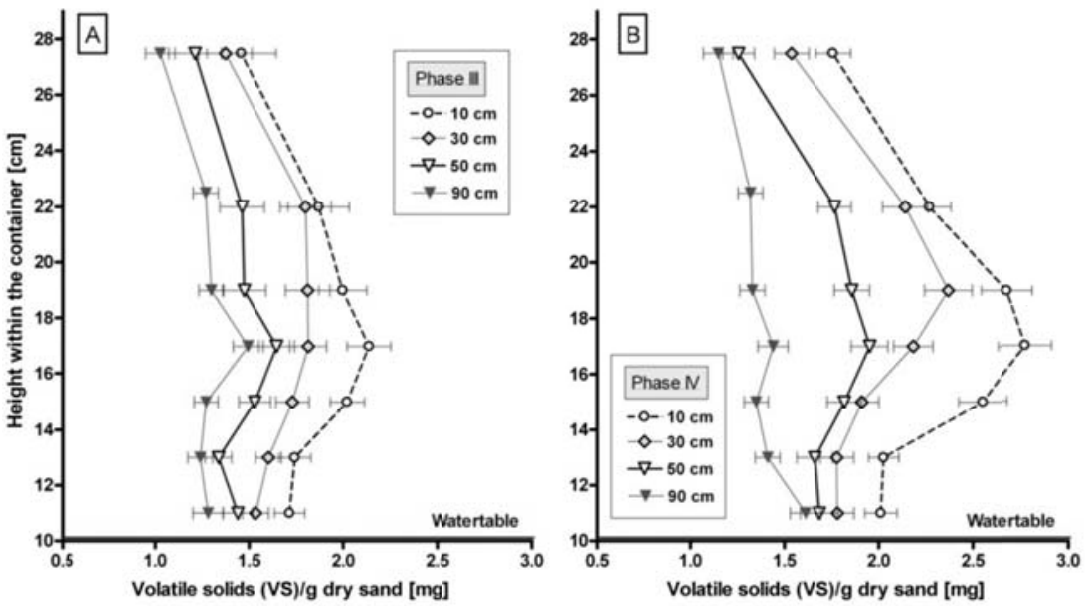

Figure S3. Amount of volatile solids (mg VS per g dry sand +/- standard deviation, $\mathrm{n}=4$ ) on sand grains within the SSC that were taken from different heights of the CF at 4 different distances $(0.1,0.3 .10 .5$ and $0.9 \mathrm{~m})$ from the inflow chamber. Results are shown for the experimental phases III and IV, which are the most relevant phases during the SSC-experiment concerning biofilm formation.
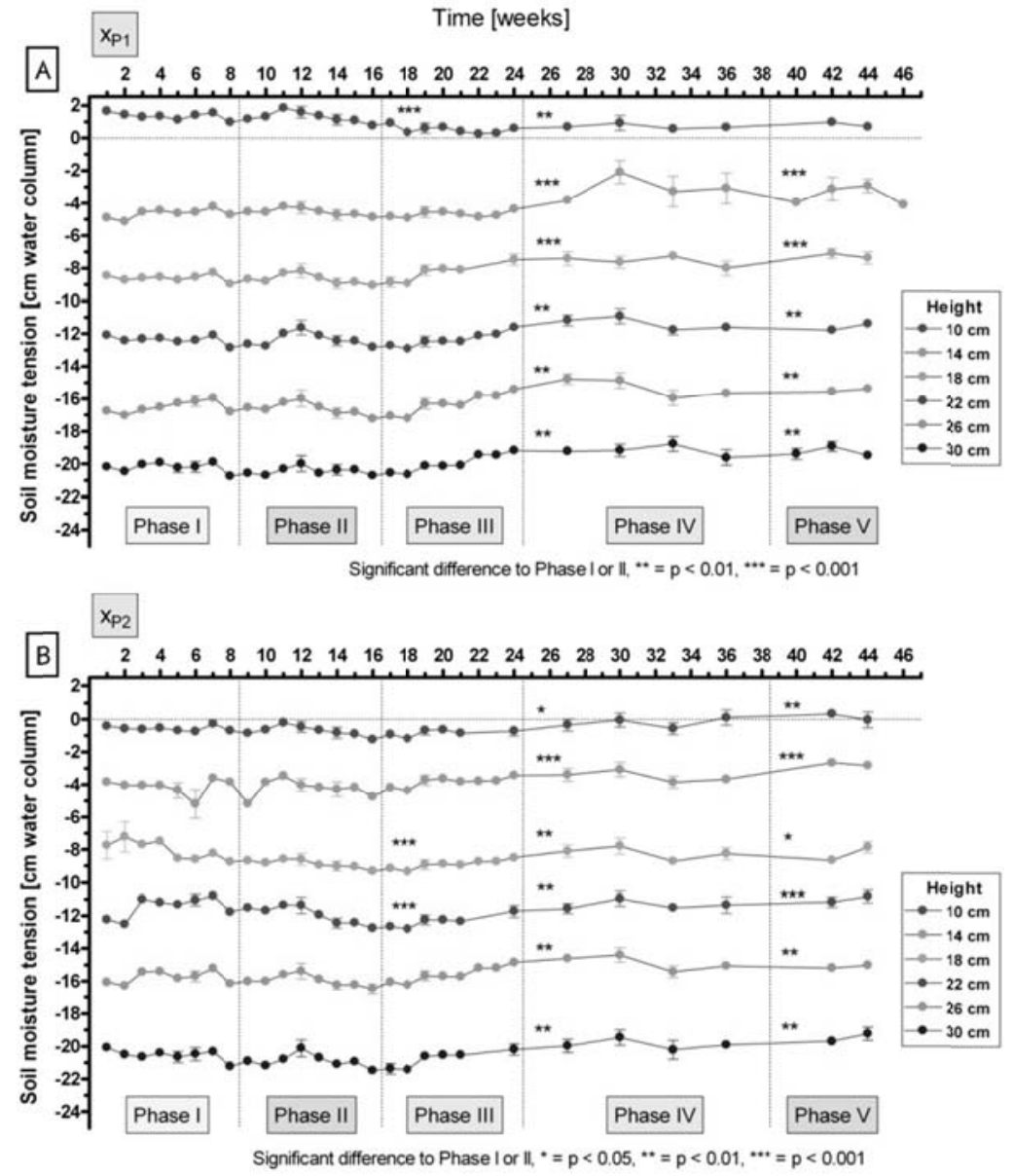

Figure S4. Soil moisture tension (cm water column or $-\mathrm{hPa}+/-$ standard deviation; $\mathrm{n}=10$ ) at positions XP1 (A) and XP2 (B) in the SSC at different heights. Significant differences in phases III, IV and V icompared to phases I or II are marked with asterisks: ${ }^{*}=\mathrm{p}<0.05,{ }^{* *}=\mathrm{p}<0.01,{ }^{* * *}=\mathrm{p}<0.001$ (Two-Way ANOVA, with Bonferroni test). 


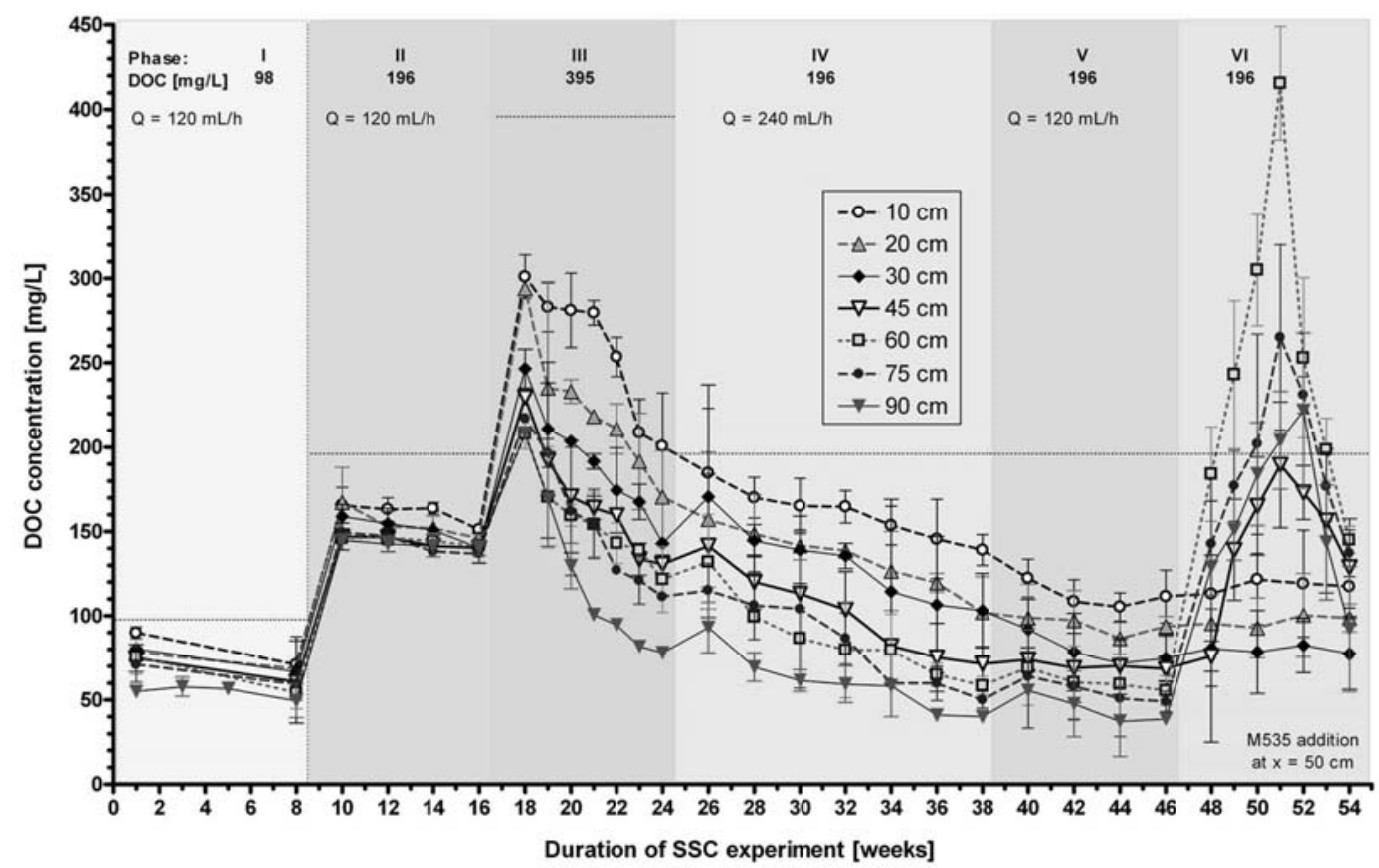

Figure S5. Dissolved organic carbon (DOC) concentrations in the aquifer of the SSC $(\mathrm{mg} / \mathrm{L}+/$ - standard deviation, $\mathrm{n}=4$ ). DOC was determined in the CF $0.02 \mathrm{~m}$ above the water table once a week during phases I - VI of the container experiment at $0.1,0.2,0.3,0.45,0.6,0.75$ and $0.9 \mathrm{~m}$ distance from the inflow chamber (see Fig. 1). Dashed lines mark the DOC concentrations in the inflowing medium during each phase.

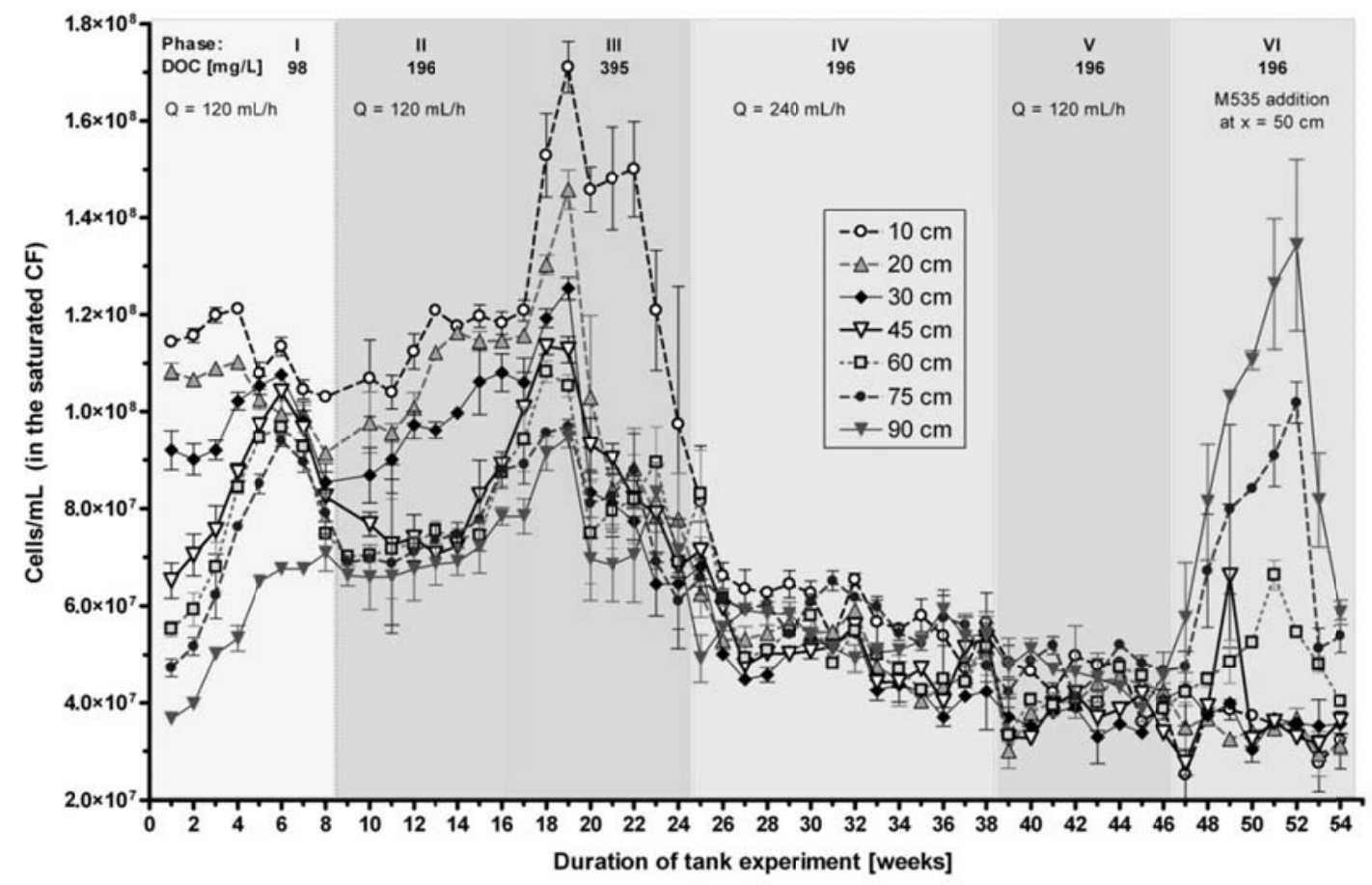

Figure S6. Cell counts in the almost saturated CF $[$ cells $/ \mathrm{mL}](+/-$ standard deviation, $\mathrm{n}=8) 0.02 \mathrm{~m}$ above the water table in the SSC during all experimental phases. Cell densities in liquid samples that were taken at $0.1,0.2$, $0.3,0.45,0.6,0.75$ and $0.9 \mathrm{~m}$ distance from the inflow chamber of the SSC were determined by counting with a Zeiss phase contrast microscope. 